\title{
Increased abundance of secreted hydrolytic enzymes and secondary metabolite gene clusters define the genomes of latent plant pathogens in the Botryosphaeriaceae
}

Jan H. Nagel*, Michael J. Wingfield and Bernard Slippers

\begin{abstract}
Background: The Botryosphaeriaceae are important plant pathogens, but also have the ability to establish asymptomatic infections that persist for extended periods in a latent state. In this study, we used comparative genome analyses to shed light on the genetic basis of the interactions of these fungi with their plant hosts. For this purpose, we characterised secreted hydrolytic enzymes, secondary metabolite biosynthetic gene clusters and general trends in genomic architecture using all available Botryosphaeriaceae genomes, and selected Dothideomycetes genomes.

Results: The Botryosphaeriaceae genomes were rich in carbohydrate-active enzymes (CAZymes), proteases, lipases and secondary metabolic biosynthetic gene clusters (BGCs) compared to other Dothideomycete genomes. The genomes of Botryosphaeria, Macrophomina, Lasiodiplodia and Neofusicoccum, in particular, had gene expansions of the major constituents of the secretome, notably CAZymes involved in plant cell wall degradation. The Botryosphaeriaceae genomes were shown to have moderate to high GC contents and most had low levels of repetitive DNA. The genomes were not compartmentalized based on gene and repeat densities, but genes of secreted enzymes were slightly more abundant in gene-sparse regions.

Conclusion: The abundance of secreted hydrolytic enzymes and secondary metabolite BGCs in the genomes of Botryosphaeria, Macrophomina, Lasiodiplodia, and Neofusicoccum were similar to those in necrotrophic plant pathogens and some endophytes of woody plants. The results provide a foundation for comparative genomic analyses and hypotheses to explore the mechanisms underlying Botryosphaeriaceae host-plant interactions.
\end{abstract}

Keywords: Secretome, CAZyme, Secondary metabolism, Comparative genomics, Endophyte, Plant cell walldegrading enzymes

\footnotetext{
* Correspondence: Jan.Nagel@fabi.up.ac.za

Department of Biochemistry, Genetics and Microbiology, Forestry and Agricultural Biotechnology Institute (FABI), University of Pretoria, Pretoria 0001, South Africa
}

(c) The Author(s). 2021 Open Access This article is licensed under a Creative Commons Attribution 4.0 International License, which permits use, sharing, adaptation, distribution and reproduction in any medium or format, as long as you give appropriate credit to the original author(s) and the source, provide a link to the Creative Commons licence, and indicate if changes were made. The images or other third party material in this article are included in the article's Creative Commons licence, unless indicated otherwise in a credit line to the material. If material is not included in the article's Creative Commons licence and your intended use is not permitted by statutory regulation or exceeds the permitted use, you will need to obtain permission directly from the copyright holder. To view a copy of this licence, visit http://creativecommons.org/licenses/by/4.0/ The Creative Commons Public Domain Dedication waiver (http://creativecommons.org/publicdomain/zero/1.0/) applies to the data made available in this article, unless otherwise stated in a credit line to the data. 


\section{Background}

Secreted hydrolytic enzymes and fungal toxins play crucial roles in enabling fungal pathogens to establish successful infections on their plant hosts. Among the secreted proteins, carbohydrate-active enzymes (CAZymes), protease and lipases are important for nutrient acquisition, as well as for the breakdown, manipulation (i.e effectors) or circumvention of host defences [17]. Fungal toxins are a diverse group of compounds and those most commonly found in fungal pathogens include polyketides, non-ribosomal peptides, terpenes and indole alkaloids [8]. These toxins are secondary metabolites that induce plant cell death, and for this reason, necrotrophic plant pathogens usually possess greater numbers of genes involved in secondary metabolite synthesis than biotrophic pathogens [9].

The genomes of many fungal and Oomycetes plant pathogens, especially those rich in repetitive elements, are not homogenous, but rather compartmentalized into repeat-rich, gene sparse regions and repeat poor, gene dense regions [10-13]. Genes localized to repeat-rich, gene sparse regions also have a higher rate of mutation and are often under stronger selective pressure [11, 14, 15]. This has given rise to a phenomenon referred to as 'two-speed' genomes, due to the stark differences in evolutionary rates between the two different types of genomic regions.

Fungi residing in the Botryosphaeriaceae include important plant pathogens. These fungi mostly cause diseases of woody plant species and they can impact negatively on the health of many economically and ecologically significant plant species $[16,17]$. The Botryosphaeriaceae infect a wide range of plant hosts, most notably grapevine [18], pome and stone fruits [19], plantation forest trees such as Eucalyptus spp., Pinus spp. and Acacia mangium [20-22], as well as plants in their native habitats [23-26]. Many of these fungi (e.g. B. dothidea, $M$. phaseolina, Lasiodiplodia theobromae, Neofusicoccum parvum) have wide host ranges, while a few species (e.g. Diplodia sapinea on Pinus species) have narrower host ranges or are even very host-specific (e.g. Eutiarosporella darliae, E. pseudodarliae and E. tritici-australis on wheat) [27]. Many species of Botryopshaeriaceae are also known to occur endophytically in asymptomatic plant tissues or to have a latent pathogenic phase, where they inhabit their plant hosts in the absence of symptoms and cause disease only after the onset of stress, such as drought, frost or hail damage $[16,28]$.

A few recent studies have investigated secreted proteins and secondary metabolites in species of the Botryosphaeriaceae. Proteomic studies analyzing the secreted proteins of Diplodia seriata [29] and D. corticola [30] identified secreted proteins involved in pathogenesis. Studies of grapevine pathogens also predicted secreted
CAZymes and genes involved in the production of secondary metabolites of D. seriata and Neofusicoccum parvum [31, 32], however no studies directly linking these genes to disease symptoms or plant interactions exist. Secondary metabolite biosynthetic gene clusters (BGCs) have also been shown to play a role in host range determination, e.g. in E. darliae and E. pseudodarliae causing white grain disorder, where the presence of a secondary metabolite biosynthetic gene cluster is likely to allow woody hosts to be infected [27]. Despite the many publicly available genomes of species of Botryosphaeriaceae [31-38], no comprehensive comparative studies have been undertaken using these genomes; neither have analyses been conducted to characterise secreted proteins and secondary metabolites in most of these fungi. Such studies are also hampered by the lack of publicly available genome annotations.

The manner in which plants interact with beneficial microorganisms, while at the same time restricting the negative effects of pathogens, is an important and intriguing question in plant biology [39]. One proposed model referred to as the 'balanced antagonism model' [40] holds that endophytism is a result of both the host plant and the fungus employing antagonistic measures against each other, in such a way that neither overwhelms the other. Disruption of this balance either results in the pathogen causing disease or in the host plant successfully killing the fungus. The model thus predicts that known endophytic species should have similar genetic repertoires to their closely related plant pathogenic relatives. This appears to be the case when considering recent comparative genomics studies conducted on endophytic fungi [41-44], although some endophytic species, e.g. Xylonia heveae had fewer CAZymes than expected and were more similar to mutualistic species [45]. Indeed, the above-mentioned endophytes (other than $X$. heveae) commonly had high numbers of plant cell wall degrading enzymes and secondary metabolite genes.

Despite their ubiquity as endophytes and their importance as latent pathogens, very little is known regarding how Botryosphaeriaceae species interact with their diverse plant hosts at a molecular level. Studies have characterized this fungus-host interaction for the most prominent of Botryosphaeriaceae species [31, 46-50], but such knowledge remains lacking for most species. Key questions in this regard relate to the secreted hydrolytic enzymes and secondary metabolic biosynthesis genes present in their genomes. Based on the results of previous studies on Ascomycetes that are endophytes of woody plants, we have hypothesised that these genes and gene clusters in the Botryosphaeriaceae will resemble those of closely related plant pathogens. To test this hypothesis, we compared the predicted secreted 
hydrolytic enzyme and secondary metabolite genes of Botryosphaeriaceae species with those of other Dothideomycetes. We also characterised the genome architecture of the Botryosphaeriaceae in terms of gene density, repeat content and prevalence of repeat-induced point mutations (RIP), and considered how these associate with secreted hydrolytic enzymes and secondary metabolite BGCs.

\section{Results}

\section{Genome sequencing, assembly and annotation}

Nine genomes of Neofusicoccum and three genomes of Lasiodiplodia species were sequenced using Illumina sequencing (Table 1). These included two isolates each of $N$. cordaticola, N. kwambonambiense, $N$. parvum and $N$. ribis were sequenced. A single isolate was sequenced for L. gonubiensis, L. pseudotheobromae, L. theobromae and N. umdonicola.

De novo genome assembly resulted in genome lengths of approximately $43 \mathrm{MB}$ for both Lasiodiplodia spp. and Neofusicoccum spp. (Table 2). The number of scaffolds/ contigs was variable between the sequenced genomes, but the three Lasiodiplodia genomes had a lower number of scaffolds (376-424) than the Neofusicoccum genomes (1343-5188). The N. parvum CMW9080 genome that was sequenced on the Miseq platform had a higher degree of fragmentation, as seen from the high total number of scaffolds (5188) and a large number of short contigs (N50: 897, L50:13.55 kb) and scaffolds (N50:830, L50: $14.81 \mathrm{~kb})$. The percentage of repetitive elements of each genome was significantly greater in the Neofusicoccum genomes (6.84\%) than in the Lasiodiplodia genomes $(3.33 \%)(p=0.004545$, Wilcoxon rank sum test).

Twenty-six Botryosphaeriaceae genomes were annotated by predicting protein-coding genes with MAKER using BRAKER trained profiles. BUSCO analysis using the Ascomycota ortholog library (Table 3 ) indicated that all Botryosphaeriaceae genomes had a high degree of completeness (average of $98 . \%$, minimum of $95.1 \%$ ). The genome annotations that were generated also had a high BUSCO completeness score (average of 97.8.\%, minimum of $94.3 \%)$. When comparing theses BUSCO results to those of species with existing genome annotations on $\mathrm{NCBI} / \mathrm{JGI}$, it was clear that in five out of the six cases the genome annotations from the present study had a higher BUSCO completeness score than the existing genome annotations.

\section{Phylogenomic analyses}

We identified 207 core orthologous genes from the collection of 26 Botryosphaeriaceae, 39 other Dothideomycetes and the outgroup (Aspergillus nidulans) genomes. Only orthologous genes that were represented by a single gene per species were retained. The results of the phylogenomic analyses corresponded well to previous phylogenies for the Dothideomycetes [74-76]. The phylogeny indicated the early divergence of the Dothideomycetidae (Dothideales, Capnodiales and Myrangiales) from the lineage containing the Pleosporomycetidae (Pleosporales, Hysteriales and Mytilinidiales) and other Dothideomycetes without current subclass designation (Fig. 1). This phylogeny further supported the early divergence of the Botryosphaeriales from the ancestral Dothideomycetes lineage after the divergence of the Dothideomycetidae and Venturiales. The phylogenetic relationships between the Botryosphaeriacaeae were well defined and the phylogenetic placement of species and genera corresponded with that found in previous studies $[77,78]$.

\section{Functional annotation}

In the Botryosphaeriaceae, both genome size and the total gene number were strongly correlated with the number of secreted proteins, CAZymes, proteases, lipases and secondary metabolite gene clusters (Additional files 1 and 2). Within the Dothideomycetes, however, the numbers of secreted proteins, CAZymes, proteases, lipases, and secondary metabolite BGCs present within a genome were correlated with one another (i.e. species that contained large numbers of secreted proteins also contained large numbers of CAZymes, proteases, lipases and secondary metabolite BGCs), but only weakly correlated with genome size and the total number of genes (Additional file 2).

Among the Botryosphaeriaceae, the Eutiarosporella spp. had the lowest number of each of functional annotation category, followed in increasing order by Diplodia spp. and Botryosphaeria, Lasiodiplodia, Macrophomina, and Neofusicoccum species (Fig. 1, Additional file 1). This observation was also evident when considering the different classes of CAZymes/proteases/lipases and the different types of secondary metabolite BGCs (Fig. 2). Furthermore, for many functional annotation categories the Botryosphaeriaceae were more similar to the Pleosporomycetidae than the Dothideomycetidae.

The genomes of the Botryosphaeriaceae genera differed significantly ( $p$-value $<0.05$ ) for many of the annotation categories (Additional file 2). All genera were significantly different (Neofusicoccum $>$ Botryosphaeriaclade $>$ Lasiodiplodia $>$ Diplodia $>$ Eutiarosporella) for the number of secreteted genes, number of total CAZymes and secreted CAZymes. This trend also existed for the other annotation categories with a few exceptions: Among the proteases and lipases, the Neofusicoccum and Botryosphaeria-clade were not significantly different. When considering the secreted proteases, species in the Botryosphaeria-clade were not significantly different to those of Lasiodiplodia, Eutiarosporella or Diplodia. The secreted lipases were not significantly 
Table 1 List of genome sequences used in this study ${ }^{\mathrm{a}}$

\begin{tabular}{|c|c|c|c|c|c|}
\hline Species & $\begin{array}{l}\text { Reference collection/ } \\
\text { Isolate number }\end{array}$ & $\begin{array}{l}\text { Assembly Size } \\
\text { (Mbp) }\end{array}$ & $\begin{array}{l}\text { Number of gene } \\
\text { models }\end{array}$ & Genome accession number & Reference \\
\hline \multicolumn{6}{|l|}{ Dothideomycetes } \\
\hline \multicolumn{6}{|l|}{ Botryosphaeriales } \\
\hline $\begin{array}{l}\text { Botryosphaeria } \\
\text { kuwatsukai }\end{array}$ & LW030101 & 47.39 & 11,278 & MDSR01000000 & {$[35,51]$} \\
\hline Botryosphaeria dothidea & CMW8000 & 43.50 & 11,368 & $\begin{array}{l}\text { http://genome.jgi.doe.gov/Botdo1_1/ } \\
\text { Botdo1_1.home.html }\end{array}$ & {$[36]$} \\
\hline Diplodia corticola & CBS112549 & 34.99 & 9376 & MNUE01000001 & {$[30]$} \\
\hline \multirow[t]{2}{*}{ Diplodia sapinea } & CBS117911 & 36.05 & 9589 & AXCF00000000 & [52] \\
\hline & CBS138184 & 35.24 & 9386 & JHUM00000000 & {$[52]$} \\
\hline Diplodia scrobiculata & CBS139796 & 34.93 & 9204 & LAEG00000000 & [53] \\
\hline \multirow[t]{2}{*}{ Diplodia seriata } & UCDDS831 & 37.12 & 9759 & MSZU00000000 & {$[32]$} \\
\hline & F98.1 & 37.27 & 9832 & LAQI00000000 & [37] \\
\hline Eutiarosporella darliae & $2 \mathrm{G} 6$ & 27.27 & 7904 & GFXH01000000 & [27] \\
\hline $\begin{array}{l}\text { Eutiarosporella } \\
\text { pseudodarliae }\end{array}$ & V4B6 & 26.74 & 7846 & GFXI01000000 & [27] \\
\hline $\begin{array}{l}\text { Eutiarosporella tritici- } \\
\text { australis }\end{array}$ & 153 & 26.59 & 7783 & GFXG01000000 & [27] \\
\hline $\begin{array}{l}\text { Lasiodiplodia } \\
\text { gonubiensis }\end{array}$ & CBS115812 & 41.14 & 10,649 & RHKH00000000 & $\begin{array}{l}\text { Present } \\
\text { study }\end{array}$ \\
\hline $\begin{array}{l}\text { Lasiodiplodia } \\
\text { pseudotheobromae }\end{array}$ & CBS116459 & 43.01 & 10,964 & RHKG00000000 & $\begin{array}{l}\text { Present } \\
\text { study }\end{array}$ \\
\hline \multirow[t]{2}{*}{$\begin{array}{l}\text { Lasiodiplodia } \\
\text { theobromae }\end{array}$} & CBS164.96 & 42.97 & 10,961 & RHKF00000000 & $\begin{array}{l}\text { Present } \\
\text { study }\end{array}$ \\
\hline & CSSO1 & 43.28 & 11,017 & RHKB00000000 & [49] \\
\hline $\begin{array}{l}\text { Macrophomina } \\
\text { phaseolina }\end{array}$ & MS6 & 48.88 & 10,799 & AHHD00000000 & [34] \\
\hline \multirow[t]{2}{*}{$\begin{array}{l}\text { Neofusicoccum } \\
\text { cordaticola }\end{array}$} & CBS123634 & 45.71 & 12,822 & RHKC00000000 & $\begin{array}{l}\text { Present } \\
\text { study }\end{array}$ \\
\hline & CBS123638 & 43.56 & 12,630 & RHKD00000000 & $\begin{array}{l}\text { Present } \\
\text { study }\end{array}$ \\
\hline \multirow[t]{2}{*}{$\begin{array}{l}\text { Neofusicoccum } \\
\text { kwambonambiense }\end{array}$} & CBS123639 & 44.17 & 12,839 & RHKE00000000 & $\begin{array}{l}\text { Present } \\
\text { study }\end{array}$ \\
\hline & CBS123642 & 44.21 & 12,904 & RKSSO0000000 & $\begin{array}{l}\text { Present } \\
\text { study }\end{array}$ \\
\hline \multirow[t]{3}{*}{$\begin{array}{l}\text { Neofusicoccum } \\
\text { parvum }\end{array}$} & CMW9080 & 41.41 & 12,870 & RHJX00000000 & $\begin{array}{l}\text { Present } \\
\text { study }\end{array}$ \\
\hline & CBS123649 & 42.16 & 12,453 & RHJY00000000 & $\begin{array}{l}\text { Present } \\
\text { study }\end{array}$ \\
\hline & UCRNP2 & 42.52 & 12,691 & AORE00000000 & [33] \\
\hline \multirow[t]{2}{*}{ Neofusicoccum ribis } & CBS115475 & 43.18 & 12,708 & RHJZ00000000 & $\begin{array}{l}\text { Present } \\
\text { study }\end{array}$ \\
\hline & CBS121.26 & 43.12 & 12,733 & RHKA00000000 & $\begin{array}{l}\text { Present } \\
\text { study }\end{array}$ \\
\hline $\begin{array}{l}\text { Neofusicoccum } \\
\text { umdonicola }\end{array}$ & CBS123644 & 42.29 & 12,816 & RHKB00000000 & $\begin{array}{l}\text { Present } \\
\text { study }\end{array}$ \\
\hline \multicolumn{6}{|l|}{ Capnodiales } \\
\hline $\begin{array}{l}\text { Acidomyces } \\
\text { richmondensis }\end{array}$ & meta & 26.82 & 10,338 & JOOL00000000 & [54] \\
\hline $\begin{array}{l}\text { Baudoinia } \\
\text { panamericana }\end{array}$ & UAMH 10762 & 21.88 & 10,508 & AEIF00000000 & [4] \\
\hline
\end{tabular}


Table 1 List of genome sequences used in this study ${ }^{a}$ (Continued)

\begin{tabular}{|c|c|c|c|c|c|}
\hline Species & $\begin{array}{l}\text { Reference collection/ } \\
\text { Isolate number }\end{array}$ & $\begin{array}{l}\text { Assembly Size } \\
\text { (Mbp) }\end{array}$ & $\begin{array}{l}\text { Number of gene } \\
\text { models }\end{array}$ & Genome accession number & Reference \\
\hline Cercospora berteroae & CBS538.71 & 33.89 & 11,903 & PNEN00000000 & {$[55]$} \\
\hline Cercospora beticola & $09-40$ & 37.06 & 12,463 & LKMD00000000 & {$[55]$} \\
\hline Cercospora zeina & CMW25467 & 40.76 & 10,193 & MVDW00000000 & {$[56]$} \\
\hline $\begin{array}{l}\text { Dothistroma } \\
\text { septosporum }\end{array}$ & NZE10 & 30.21 & 12,415 & AIEN00000000 & [4] \\
\hline $\begin{array}{l}\text { Pseudocercospora } \\
\text { eumusae }\end{array}$ & CBS 114824 & 47.12 & 12,632 & LFZN01000000 & [57] \\
\hline $\begin{array}{l}\text { Pseudocercospora } \\
\text { fijiensis }\end{array}$ & CIRAD86 & 29.98 & 13,066 & AlHZ00000000 & [4] \\
\hline $\begin{array}{l}\text { Pseudocercospora } \\
\text { musae }\end{array}$ & CBS 116634 & 60.44 & 13,129 & LFZO00000000 & {$[57]$} \\
\hline Ramularia collo-cygni & URUG2 & 32.25 & 11,612 & FJUY00000000 & [58] \\
\hline Sphaerulina musiva & SO2202 & 29.35 & 10,233 & AEFD00000000 & [4] \\
\hline Zymoseptoria tritici & IPO323 & 39.69 & 10,963 & ACPE00000000 & {$[59]$} \\
\hline \multicolumn{6}{|l|}{ Dothideales } \\
\hline $\begin{array}{l}\text { Aureobasidium } \\
\text { namibiae }\end{array}$ & CBS 147.97 & 25.43 & 10,259 & AYEM00000000 & [60] \\
\hline $\begin{array}{l}\text { Aureobasidium } \\
\text { subglaciale }\end{array}$ & EXF-2481 & 25.80 & 10,792 & AYYB00000000 & {$[60]$} \\
\hline \multicolumn{6}{|l|}{ Hysteriales } \\
\hline Hysterium pulicare & CBS 123377 & 38.43 & 12,352 & AJFK00000000 & {$[4]$} \\
\hline Rhytidhysteron rufulum & CBS 306.38 & 40.18 & 12,117 & AJFL00000000 & {$[4]$} \\
\hline \multicolumn{6}{|l|}{ Myriangiales } \\
\hline Elsinoe australis & NL1 & 23.34 & 9223 & NHZQ00000000 & [7] \\
\hline \multicolumn{6}{|l|}{ Mytilinidiales } \\
\hline Lepidopterella palustris & CBS 459.81 & 45.67 & 13,861 & LKAR00000000 & {$[61]$} \\
\hline \multicolumn{6}{|l|}{ Pleosporales } \\
\hline Alternaria alternata & SRC1IrK2f & 32.99 & 13,466 & LXPP00000000 & [62] \\
\hline Ascochyta rabiei & ArD\|l & 34.66 & 10,596 & JYNV00000000 & [63] \\
\hline Bipolaris maydis & ATCC 48331 & 32.93 & 12,705 & AlHU00000000 & [4] \\
\hline Bipolaris oryzae & ATCC 44560 & 31.36 & 12,002 & AMCO00000000 & [64] \\
\hline Bipolaris sorokiniana & ATCC 44560 & 34.41 & 12,214 & AEIN00000000 & [64] \\
\hline Bipolaris victoriae & $\mathrm{Fl3}$ & 32.83 & 12,882 & AMCY00000000 & [64] \\
\hline Bipolaris zeicola & $26-R^{-13}$ & 31.27 & 12,853 & AMCN00000000 & [64] \\
\hline $\begin{array}{l}\text { Clohesyomyces } \\
\text { aquaticus }\end{array}$ & CBS 115471 & 49.68 & 15,811 & MCFA00000000 & [65] \\
\hline Corynespora cassiicola & $\mathrm{CCP}$ & 44.85 & 17,158 & NSJI00000000 & [66] \\
\hline Epicoccum nigrum & ICMP 19927 & 34.74 & 12,025 & NCTX00000000 & [67] \\
\hline Exserohilum turcicum & Et28A & 43.01 & 11,698 & AlHT00000000 & [4] \\
\hline Leptosphaeria maculans & JN3 & 45.12 & 12,469 & FP929064:FP929139 & [12] \\
\hline $\begin{array}{l}\text { Paraphaeosphaeria } \\
\text { sporulosa }\end{array}$ & AP3s5-JAC2a & 38.46 & 14,734 & LXPO00000000 & {$[62]$} \\
\hline $\begin{array}{l}\text { Parastagonospora } \\
\text { nodorum }\end{array}$ & SN15 & 37.21 & 15,994 & AAGI00000000 & {$[68]$} \\
\hline Periconia macrospinosa & DSE2036 & 54.99 & 18,735 & PCYO00000000 & [69] \\
\hline $\begin{array}{l}\text { Pyrenophora tritici- } \\
\text { repentis }\end{array}$ & Pt-1C-BFP & 38.00 & 12,169 & AAXI00000000 & [70] \\
\hline
\end{tabular}


Table 1 List of genome sequences used in this study ${ }^{a}$ (Continued)

\begin{tabular}{|c|c|c|c|c|c|}
\hline Species & $\begin{array}{l}\text { Reference collection/ } \\
\text { Isolate number }\end{array}$ & $\begin{array}{l}\text { Assembly Size } \\
\text { (Mbp) }\end{array}$ & $\begin{array}{l}\text { Number of gene } \\
\text { models }\end{array}$ & Genome accession number & Reference \\
\hline Stemphylium lycopersici & CIDEFI 216 & 35.17 & 8997 & LGLR00000000 & [71] \\
\hline \multicolumn{6}{|l|}{ Venturiales } \\
\hline Verruconis gallopava & CBS 43764 & 31.78 & 11,357 & JYBX00000000 & {$[72]$} \\
\hline \multicolumn{6}{|l|}{ incertae sedis } \\
\hline Cenococcum geophilum & 1.58 & 177.56 & 14,709 & LKKR00000000 & [61] \\
\hline Coniosporium apollinis & CBS 100218 & 28.65 & 9308 & AJKL00000000 & [72] \\
\hline Glonium stellatum & CBS 207.34 & 40.52 & 14,277 & LKAO00000000 & [61] \\
\hline \multicolumn{6}{|l|}{ Eurotiomycetes } \\
\hline \multicolumn{6}{|l|}{ Eurotiales } \\
\hline Aspergillus nidulans & FGSC A4 & 30.28 & 9556 & AACD00000000 & [73] \\
\hline
\end{tabular}

${ }^{a}$ Entries in boldface represent genomes that were sequenced as part of the present study

Table 2 Genome statistics of new draft Botryosphaeriaceae genomes

\begin{tabular}{|c|c|c|c|c|c|c|c|c|c|}
\hline & $\begin{array}{l}\# \\
\text { scaffolds }\end{array}$ & $\begin{array}{l}\# \\
\text { contigs }\end{array}$ & $\begin{array}{l}\text { Scaffold } \\
\text { length } \\
\text { (Mb) }\end{array}$ & $\begin{array}{l}\text { Contig } \\
\text { length } \\
\text { (Mb) }\end{array}$ & $\begin{array}{l}\text { Genome } \\
\text { scaffold N50/ } \\
\text { L50 (\#/kb) }\end{array}$ & $\begin{array}{l}\text { Genome } \\
\text { contig N50/ } \\
\text { L50 (\#/kb) }\end{array}$ & $\begin{array}{l}\text { Maximum } \\
\text { scaffold } \\
\text { length (Mb) }\end{array}$ & $\begin{array}{l}\text { Maximum } \\
\text { contig } \\
\text { length (kb) }\end{array}$ & $\begin{array}{l}\text { \% main } \\
\text { genome in } \\
\text { scaffolds }>50 \\
\text { KB }\end{array}$ \\
\hline $\begin{array}{l}\text { Lasiodiplodia } \\
\text { gonubiensis } \\
\text { CBS115812 }\end{array}$ & 376 & 1578 & 41.14 & 40.97 & $50 / 234.83$ & $267 / 45.4$ & 1.06 & 226.76 & 0.92 \\
\hline $\begin{array}{l}\text { Lasiodiplodia } \\
\text { pseudotheobromae } \\
\text { CBS116459 }\end{array}$ & 403 & 1285 & 43.01 & 42.89 & $48 / 236.23$ & 218/61.88 & 1.03 & 416.59 & 0.91 \\
\hline $\begin{array}{l}\text { Lasiodiplodia } \\
\text { theobromae } \\
\text { CBS164.96 }\end{array}$ & 424 & 1093 & 42.97 & 42.88 & $48 / 223.84$ & $163 / 81.56$ & 1.69 & 591.21 & 0.91 \\
\hline $\begin{array}{l}\text { Neofusicoccum } \\
\text { cordaticola } \\
\text { CBS123634 }\end{array}$ & 1912 & 8698 & 45.71 & 45.10 & $276 / 47.38$ & $1218 / 10.76$ & 680.02 & 143.71 & 0.48 \\
\hline $\begin{array}{l}\text { Neofusicoccum } \\
\text { cordaticola } \\
\text { CBS123638 }\end{array}$ & 2393 & 3252 & 43.56 & 43.44 & $254 / 51.16$ & $386 / 33.04$ & 274.15 & 152.21 & 0.51 \\
\hline $\begin{array}{l}\text { Neofusicoccum } \\
\text { kwambonambiense } \\
\text { CBS123639 }\end{array}$ & 1560 & 2839 & 44.17 & 43.99 & 219/59.44 & $363 / 34.21$ & 344.53 & 186.24 & 0.58 \\
\hline $\begin{array}{l}\text { Neofusicoccum } \\
\text { kwambonambiense } \\
\text { CBS123642 }\end{array}$ & 1717 & 2871 & 44.21 & 44.06 & 210/61.88 & $352 / 34.6$ & 387.07 & 262.94 & 0.58 \\
\hline $\begin{array}{l}\text { Neofusicoccum } \\
\text { parvum CBS123649 }\end{array}$ & 2185 & 6686 & 42.16 & 41.76 & $312 / 39.13$ & $995 / 12.5$ & 439.22 & 92.09 & 0.40 \\
\hline $\begin{array}{l}\text { Neofusicoccum } \\
\text { parvum CMW9080 }\end{array}$ & 5188 & 5739 & 41.41 & 41.39 & $830 / 14.81$ & $897 / 13.55$ & 99.22 & 80.57 & 0.04 \\
\hline $\begin{array}{l}\text { Neofusicoccum ribis } \\
\text { CBS115475 }\end{array}$ & 1994 & 3261 & 43.18 & 43.03 & $301 / 42.08$ & $474 / 26.80$ & 231.82 & 186.29 & 0.43 \\
\hline $\begin{array}{l}\text { Neofusicoccum ribis } \\
\text { CBS121.26 }\end{array}$ & 2417 & 3145 & 43.12 & 43.03 & $245 / 51.65$ & $371 / 33.92$ & 280.49 & 167.59 & 0.51 \\
\hline $\begin{array}{l}\text { Neofusicoccum } \\
\text { umdonicola } \\
\text { CBS123644 }\end{array}$ & 1343 & 2424 & 42.29 & 42.15 & $165 / 73.88$ & $345 / 36.48$ & 422.57 & 210.10 & 0.67 \\
\hline
\end{tabular}


Table 3 Genome and genome annotation completeness assesment ${ }^{a}$

\begin{tabular}{|c|c|c|c|c|c|c|c|c|c|c|c|c|c|c|c|}
\hline \multirow[b]{2}{*}{ Genome } & \multicolumn{5}{|c|}{ Genome BUSCO \% } & \multicolumn{5}{|c|}{ Current annotation BUSCO \% } & \multicolumn{5}{|c|}{ Prior annotation BUSCO \% } \\
\hline & $\mathrm{C}$ & $S$ & D & $\mathrm{F}$ & $M$ & $\mathrm{C}$ & $S$ & D & $F$ & $M$ & $\mathrm{C}$ & $S$ & D & $\mathbf{F}$ & M \\
\hline Botryosphaeria kuwatsukai LW030101 & 99.2 & 98.9 & 0.3 & 0.1 & 0.7 & 98.4 & 98.1 & 0.3 & 0.6 & 1.0 & & & & & \\
\hline Botryosphaeria dothidea CMW8000 & 99.0 & 98.6 & 0.4 & 0.3 & 0.7 & 98.5 & 98.1 & 0.4 & 0.5 & 1.0 & 98.1 & 97.7 & 0.4 & 0.3 & 1.6 \\
\hline Diplodia corticola CBS112549 & 98.9 & 98.7 & 0.2 & 0.1 & 1.0 & 98.7 & 98.6 & 0.1 & 0.5 & 0.8 & 99.4 & 99.2 & 0.2 & 0.3 & 0.3 \\
\hline Diplodia sapinea CBS117911 & 98.0 & 97.8 & 0.2 & 0.5 & 1.5 & 97.6 & 97.5 & 0.1 & 0.9 & 1.5 & & & & & \\
\hline Diplodia sapinea CBS138184 & 96.0 & 95.8 & 0.2 & 0.8 & 3.2 & 95.6 & 95.4 & 0.2 & 1.2 & 3.2 & & & & & \\
\hline Diplodia scrobiculata CBS139796 & 95.4 & 95.2 & 0.2 & 2.3 & 2.3 & 95.0 & 94.8 & 0.2 & 1.8 & 3.2 & & & & & \\
\hline Diplodia seriata UCDDS831 & 99.1 & 98.9 & 0.2 & 0.2 & 0.7 & 98.8 & 98.7 & 0.1 & 0.5 & 0.7 & 87 & 86.9 & 0.1 & 5.9 & 7.1 \\
\hline Diplodia seriata F98.1 & 99.3 & 98.9 & 0.4 & 0.1 & 0.6 & 98.9 & 98.5 & 0.4 & 0.5 & 0.6 & 90.1 & 89.9 & 0.2 & 2.6 & 7.3 \\
\hline Eutiarosporella darliae $2 \mathrm{G} 6$ & 98.1 & 97.8 & 0.3 & 0.6 & 1.3 & 98.5 & 97.8 & 0.7 & 0.5 & 1.0 & & & & & \\
\hline Eutiarosporella pseudodarliae V4B6 & 98.2 & 98.0 & 0.2 & 0.6 & 1.2 & 98.1 & 97.8 & 0.3 & 0.7 & 1.2 & & & & & \\
\hline Eutiarosporella tritici-australis 153 & 98.3 & 98.0 & 0.3 & 0.4 & 1.3 & 98.6 & 98.4 & 0.2 & 0.4 & 1.0 & & & & & \\
\hline Lasiodiplodia gonubiensis CBS115812 & 97.2 & 97.1 & 0.1 & 0.2 & 2.6 & 98.3 & 98.2 & 0.1 & 0.8 & 0.9 & & & & & \\
\hline Lasiodiplodia pseudotheobromae CBS116459 & 99.1 & 98.9 & 0.2 & 0.2 & 0.7 & 98.3 & 98.0 & 0.3 & 0.8 & 0.9 & & & & & \\
\hline Lasiodiplodia theobromae CBS164.96 & 97.2 & 97.0 & 0.2 & 0.2 & 2.6 & 98.6 & 98.2 & 0.4 & 0.5 & 0.9 & & & & & \\
\hline Lasiodiplodia theobromae CSSO1 & 99.1 & 98.7 & 0.4 & 0.0 & 0.9 & 99.1 & 98.7 & 0.4 & 0.4 & 0.5 & & & & & \\
\hline Macrophomina phaseolina MS6 & 98.9 & 98.7 & 0.2 & 0.0 & 1.1 & 98.1 & 97.9 & 0.2 & 0.8 & 1.1 & 91.2 & 91 & 0.2 & 4.5 & 4.3 \\
\hline Neofusicoccum cordaticola CBS123634 & 97.0 & 94.9 & 2.1 & 0.9 & 2.1 & 96.1 & 94.2 & 1.9 & 1.6 & 2.3 & & & & & \\
\hline Neofusicoccum cordaticola CBS123638 & 98.5 & 98.0 & 0.5 & 0.5 & 1.0 & 98.3 & 97.9 & 0.4 & 0.6 & 1.1 & & & & & \\
\hline Neofusicoccum kwambonambiense CBS123639 & 99.0 & 98.6 & 0.4 & 0.3 & 0.7 & 98.6 & 98.2 & 0.4 & 0.7 & 0.7 & & & & & \\
\hline Neofusicoccum kwambonambiense CBS123642 & 98.9 & 98.4 & 0.5 & 0.4 & 0.7 & 98.8 & 98.3 & 0.5 & 0.5 & 0.7 & & & & & \\
\hline Neofusicoccum parvum CMW9080 & 95.4 & 95.0 & 0.4 & 2.0 & 2.6 & 94.3 & 93.9 & 0.4 & 2.0 & 3.7 & & & & & \\
\hline Neofusicoccum parvum CBS123649 & 95.1 & 94.5 & 0.6 & 0.9 & 4.0 & 96.4 & 95.9 & 0.5 & 1.3 & 2.3 & & & & & \\
\hline Neofusicoccum parvum UCRNP2 & 98.1 & 97.9 & 0.2 & 0.5 & 1.4 & 97.8 & 97.6 & 0.2 & 0.9 & 1.3 & 84.9 & 84.8 & 0.1 & 6.6 & 8.5 \\
\hline Neofusicoccum ribis CBS115475 & 98.3 & 97.9 & 0.4 & 0.9 & 0.8 & 97.6 & 97.2 & 0.4 & 1.3 & 1.1 & & & & & \\
\hline Neofusicoccum ribis CBS121.26 & 98.7 & 98.3 & 0.4 & 0.6 & 0.7 & 98.2 & 97.7 & 0.5 & 1.2 & 0.6 & & & & & \\
\hline Neofusicoccum umdonicola CBS123644 & 98.7 & 98.2 & 0.5 & 0.5 & 0.8 & 98.1 & 97.5 & 0.6 & 1.1 & 0.8 & & & & & \\
\hline
\end{tabular}

${ }^{\mathrm{a} B U S C O}$ percentages for Complete (C), single (S), duplicated (D), fragmented (F) and missing (M) genes. Assesments were done using the Ascomycota ortholog library

different between Eutiarosporella and Diplodia. The secondary metabolite BGCs were not significantly different between the Neofusicoccum and species in the Botryosphaeria-clade.

Significant differences also existed when comparing the functional annotation categories of the Botryosphaeriaceae to the rest of the Dothideomycetes (Additional file 2). The Botryosphaeriaceae had significantly greater numbers of secreted genes, total CAZymes and total proteases than the Dothideomycetidae. Furthermore, the Botryosphaeriaceae had significantly greater numbers of secreted CAZymes, secreted proteases, both total and secreted lipases and secondary metabolite BGCs than both Dothideomycetidae and Pleosporomycetidae.

The Botryosphaeriaceae, had significantly more CAZymes of the auxiliary activities (AA), carbohydratebinding modules (CBM), carbohydrate esterases (CE) and glycoside hydrolases $(\mathrm{GH})$ classes than
Dothideomycetidae (Fig. 2, Additional file 2). Additionally, the Botryosphaeriaceae had significantly more polysaccharide lyase (PL) genes than both Dothideomycetidae and Pleosporomycetidae. Conversely, significantly fewer CEs were present in the Botryosphaeriaceae than in the Pleosporomycetidae, as well as fewer glycosyltransferases (GT) than the other two Dothideomycetes sub-classes.

When considering the secreted CAZyme classes, the Botryosphaeriaceae had significantly more CAZymes of the AA, CBM and CE classes than Dothideomycetidae and significantly more GH and PL classes than both Dothideomycetidae and Pleosporomycetidae (Fig. 2, Additional file 2). The most abundant secreted CAZyme families in the Botryosphaeriaceae were CBM1, AA3, GH3, GH43, GH5, AA9, CBM18, AA1, GH28 and CBM13 (Additional file 1). 


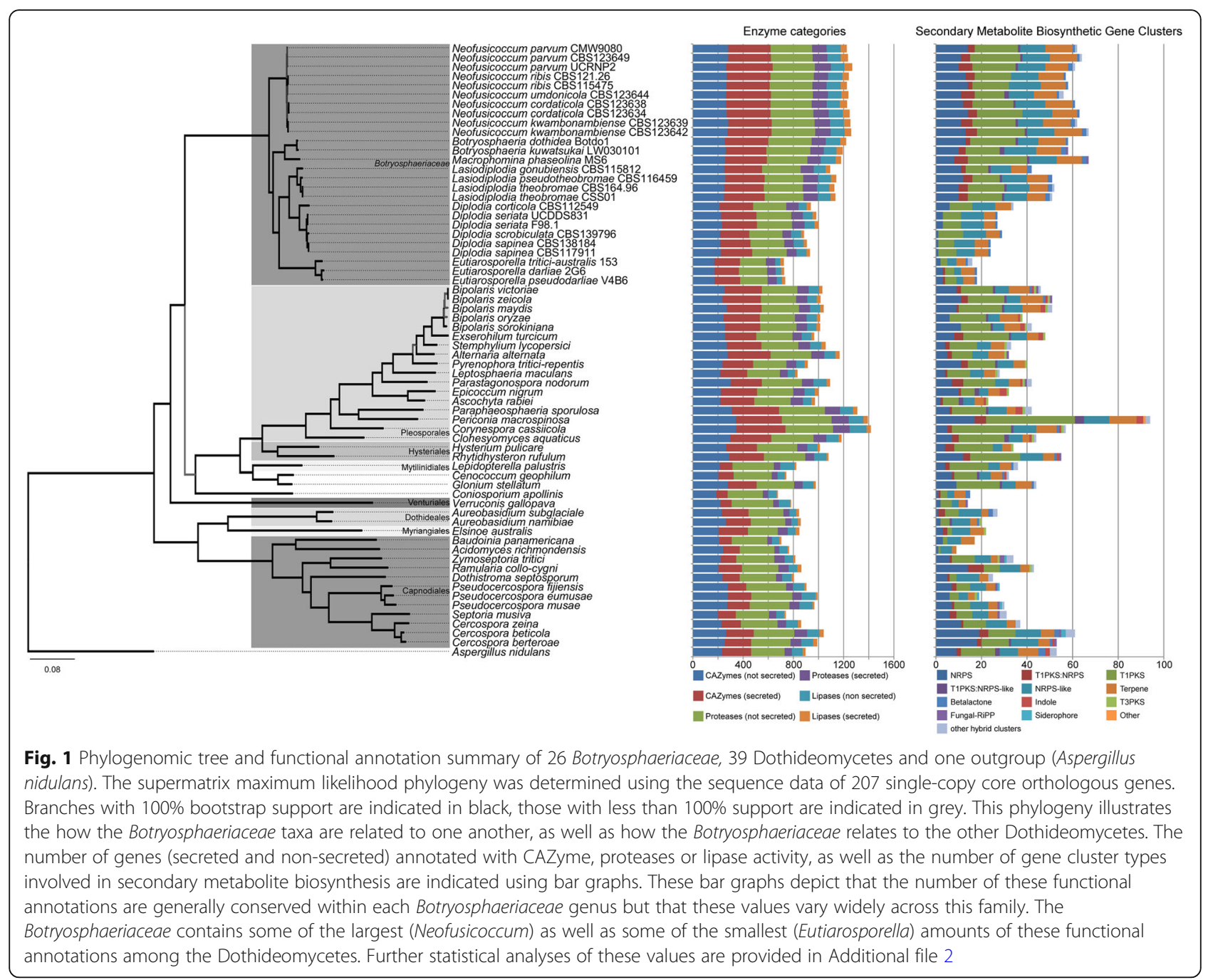

The Botryosphaeriaceae had above-average numbers of aspartic- (A), metallo- (M) and serine- (S) proteases, especially in the species of Botryosphaeria, Lasiodiplodia, Macrophomina, and Neofusicoccum (Fig. 2). For both the total and secreted number of predicted aspartic and serine proteases, the Botrosphaeriaceae had significantly greater levels than the Dothideomycetidae and Pleosporomycetidae (Fig. 2, Additional file 2). The total and secreted metallo-proteases of the Botryosphaeriaceae were significantly higher than those of the Dothideomycetidae. These three protease classes were also the dominant proteases in the secretome. Furthermore, the Botryosphaeriaceae had significantly fewer secreted cysteine (C) proteases and protease inhibitors (I) than the other Dothideomycetes. Notably, the Botryosphaeriaceae possessed a single secreted protease inhibitor family, namely I51.001 (serine carboxypeptidase Y inhibitor), whereas many other Dothideomycetes secreted protease inhibitors were of this family, as well as I09.002 (peptidase A inhibitor 1) or I09.003 (peptidase B inhibitor). Diplodia sapinea and D. scrobiculata had no secreted protease inhibitors. The most abundant secreted protease families among the Botryosphaeriaceae were S09, A01, S10, S08, M28, S53, S33, M43, M35 and S12 (Additional file 1).

In the Botryosphaeriaceae and the Dothideomycetes, the most abundant lipases/lipase-like families were abH04 (Moraxella lipase 2 like), abH03 (Candida rugosa lipase-like), abH36, (cutinase) and abH23 (Filamentous fungi lipases) (Fig. 2). The abH03, abH36 and abH23 lipase families were the main constituents of the predicted secretomes among the Dothideomycetes and the Botryosphaeriaceae had significantly more of these secreted enzymes than the Dothideomycetidae and Pleosporomycetidae (Additional file 2).

The Botryosphaeriaceae genomes were rich in gene clusters involved in the synthesis of secondary metabolites (Fig. 2). Type 1 polyketide synthases (t1PKS) were the most abundant type of gene cluster, followed by non-ribosomal peptide synthetases (NRPS) and NRPSlike, terpene synthases (TS) and t1PKS-NRPS hybrid 


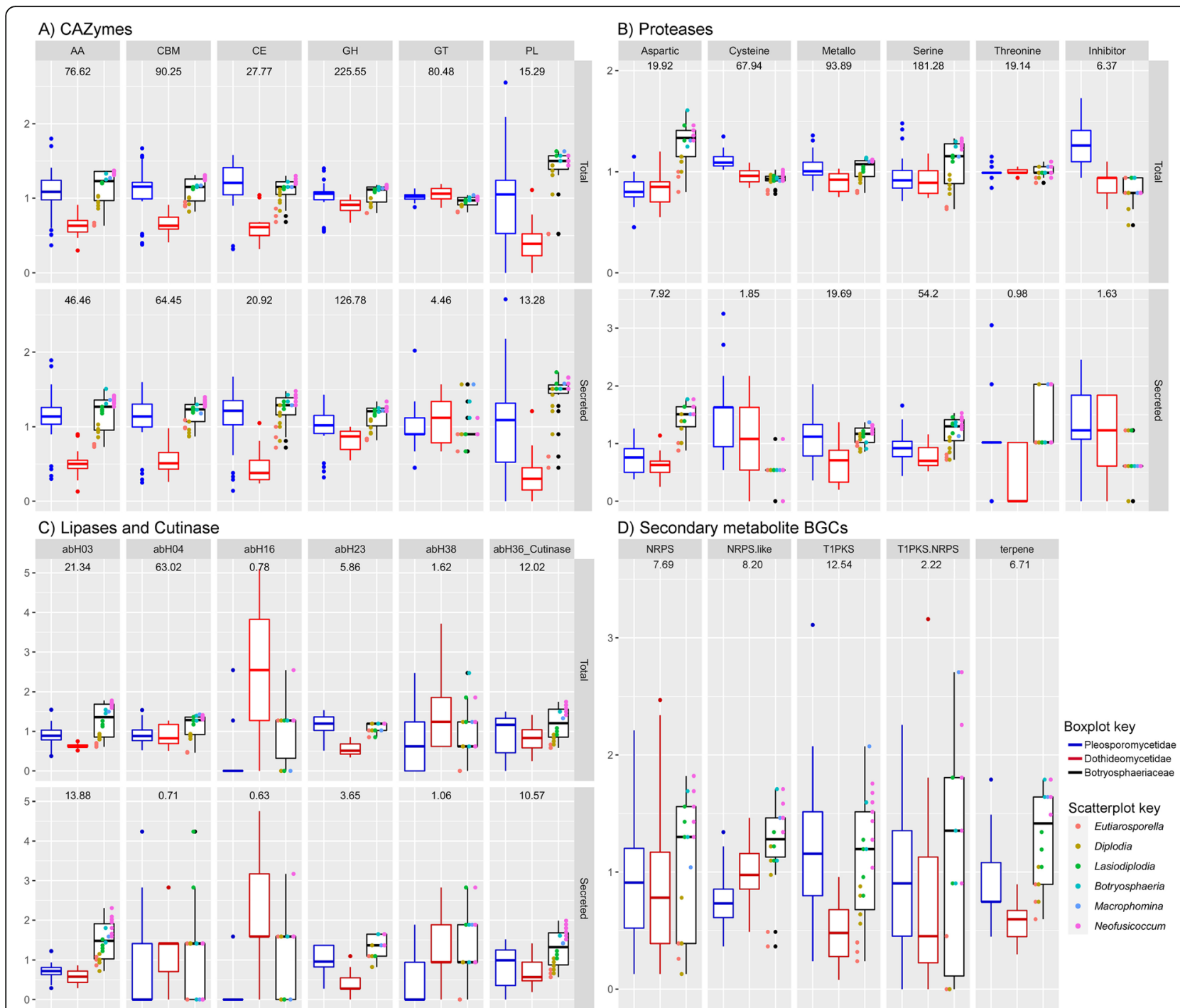

Fig. 2 Box-and-whisker plots of the number of prominent CAZyme, protease and lipase classes (total and secreted) and secondary metabolite BGC types present within the genomes of the considered Botryosphaeriaceae and other Dothideomycetes taxa. Represented data is scaled using the mean of each class/type and is indicated by the number appearing at the top of each facet. Taxa are placed into three categories: Dothideomycetidae, Pleosporomycetidae (plus related taxa without subclass designation) and Botryosphaeriaceae. The upper and lower bounds of the box represent the 1st and 3rd quartiles (respectively) and the bar inside represent the median. The error lines (whiskers) represents 1.5 times the interquartile range (IQR) and outliers are indicated as dots. Additionally, the genera of the Botryosphaeriaceae are indicated by means of a scatterplot overlain on the Botryosphaeriaceae box-and-whisker plot. These graphs visually compares the variance of each functional annotation class between the Botryosphaeriaceae and other Dothideomycetes subclasses. It also depicts that, among the Botryosphaeriaceae, the Eutiarosporella and Diplodia have smaller amounts of most functional annotation classes than the other genera

clusters. The Botryosphaeriaceae had significantly more t1PKS clusters than the Dothideomycetidae and more NRPS-like, TS and betalactone clusters than both Dothideomycetidae and Pleosporomycetidae (Additional file 2). Certain Dothideomycetes genomes, predominantly those of the Pleosporomycetidae also contained indole and type 3 PKS BGCs, however, these were not present in any of the Botryosphaeriaceae genomes.

The most abundant secreted CAZyme, protease and lipase families of the Botryosphaeriaceae were also those that had the greatest difference from the rest of the Dothideomycetes (Table 4, Additional file 2). The twenty most abundant secreted hydrolytic enzyme families of the Botryosphaeriaceae were all significantly greater that both the Dothideomycetidae and Pleosporomycetidae, with the exception of the secreted CBM1 and AA9 CAZymes and the M28 metalloprotease families of the Botryosphaeriaceae that were not significantly greater than those of the Pleosporomycetidae. Furthermore, these twenty most abundant secreted families of the 


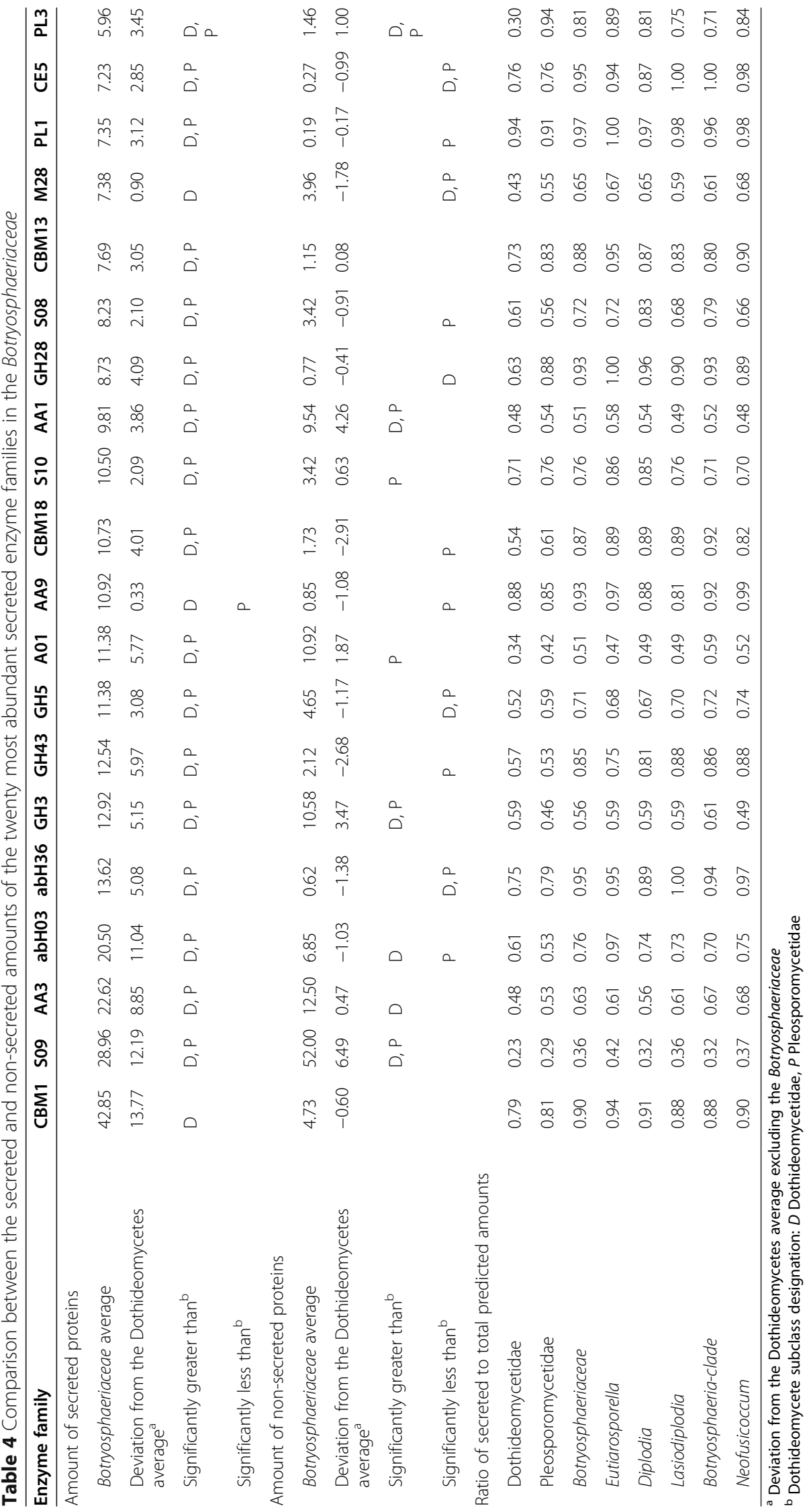


Botryosphaeriaceae were also those that had, on average, the highest deviation from the Dothideomycetes average. The number of genes in these gene families were not increased among the non-secreted proteins. Consequently, the ratio of secreted to total proteins for these gene families was higher among the Botryosphaeriaceae than in the the Dothideomycetidae and Pleosporomycetidae.

\section{Gene family evolution}

These results of the CAFE analyses (Additional file 3) indicated that expansions and contractions of CAZyme gene families occurred at roughly similar levels. This was after the divergence of the Botryosphaeriales ancestor from the Pleosporomycetidae until the formation of the Botryosphaeriaceae crown group (61 MYA) [79]. During this time, protease gene families experienced more contractions than expansions, lipase gene families had slightly more expansions than contractions and secondary metabolite BGCs experienced a large amount of gene family contractions. Several CAZyme gene families (AA1, AA3, AA7, AA8, AA9, CBM1, CBM18, CE4, CE5, GH3, GH10, GH28, GH43, GH78, GT1, GT2, GT25, PL1 and PL3) experienced rapid expansion (i.e. greater than expected under the birth/death model of gene family evolution) prior to the divergence of the Botryosphaeriaceae crown group.

After the divergence of the Botryosphaeriaceae, the genera Botryosphaeria, Lasiodiplodia, Macrophomina and Neofusicoccum experienced more gene family expansions than contractions, whereas the opposite was observed for the Diplodia and Eutiariosporella. Among the Neofusicoccum spp., the AA3, AA7, GH3 and GT2 gene families were rapidly expanding. Similarly, among the Lasiodiplodia spp., the AA7 and GH106 gene families were rapidly expanding. Conversely, among the Diplodia spp. the AA7 gene family was rapidly contracting, as were the AA1, AA3, AA7, GH28, PL1 and PL3 gene families among the Eutiarosporella spp.

\section{Principal component analysis and hierarchical clustering}

Hierarchical clustering separated the taxa into four groups (Fig. 3). The taxa in the Pleosporomycetidae and Dothideomycetidae generally clustered separately, however, there was no overall clustering based on taxonomic placement. Botryosphaeriaceae species were present in three of the four dominant clusters.

A first cluster included B. dothidea, B. kuwatsukai, $M$. phaseolina, L. theobromae, L. pseudotheobromae and

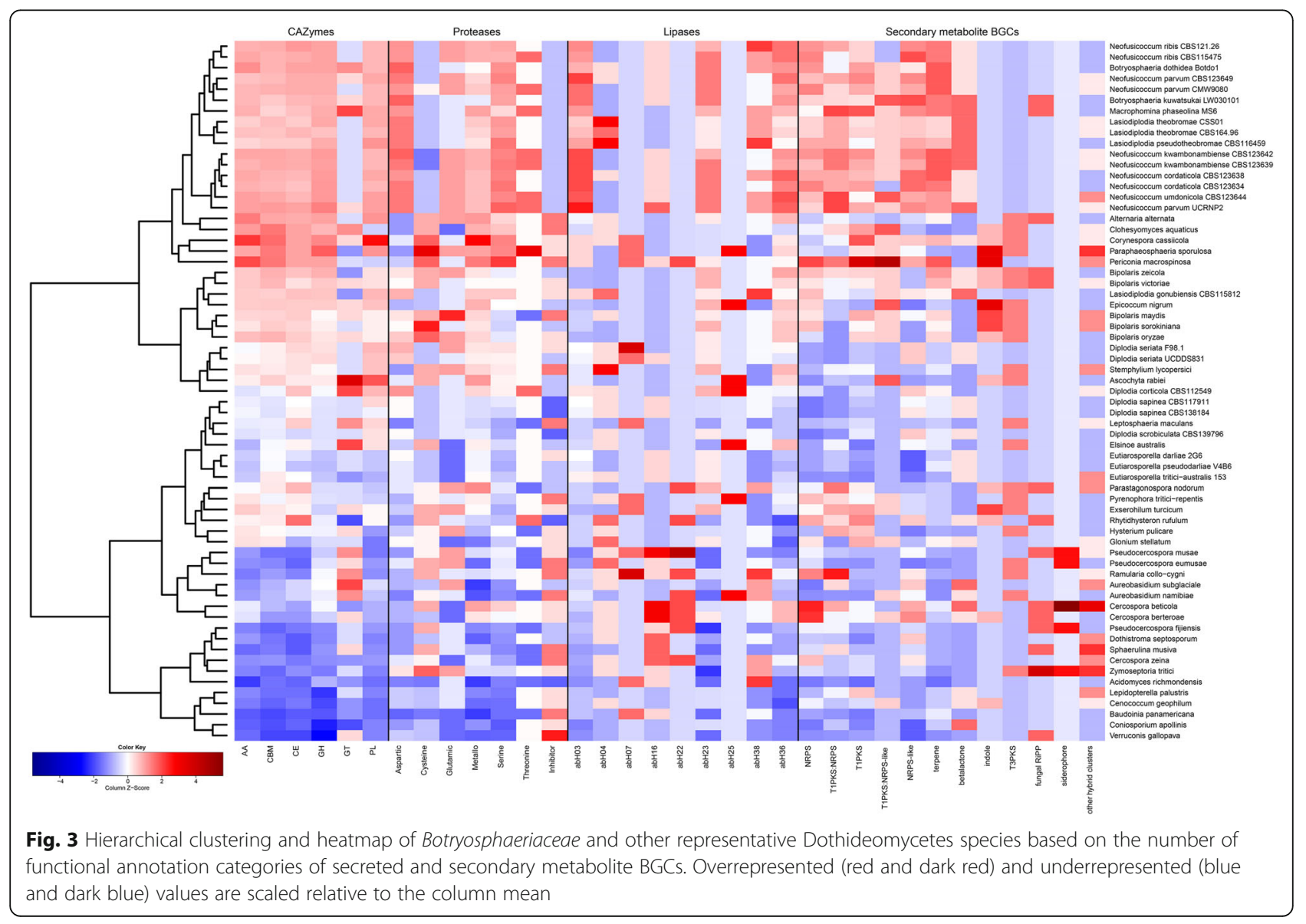


Neofusicoccum spp., as well as several Pleosporales (Alternaria alternata, Clohesyomyces aquaticus, Corynespora cassiicola Paraphaeosphaeria sporulosa and Periconia macrospinosa). A second cluster mostly contained taxa from the Pleosporales (Aschochyta rabiei, Bipolaris spp., Epicoccum nigrum and Stemphylium lycopersici), but also contained D. seriata, D. corticola and L. gonubiensis. A third cluster contained taxa from both the Dothideomycetidae and Pleosporomycetidae, as well as D. sapinea, D. scrobiculata and Eutiarosporella spp. A fourth cluster was dominated by taxa from the Dothideomycetidae with the exception of L. palustris, C. geophilum, C. apollinis and V. gallopava.

PCA of the functional annotation categories clustered the data along 65 dimensions/principal components. The first two dimensions (Fig. 4) accounted for $29.9 \%$ of the variance among the taxa. The first dimension accounted for $17.4 \%$ and the second dimension for $12.5 \%$ of the variance. The first dimension was most strongly influenced by several secreted CAZyme (AA3, CBM1, GH131, PL3, CBM13, CBM18, CE8, CE12, AA7, GH43, PL4, PL1, CE5 and CBM63), cutinase (abH36) and lipase (abH03 and abH23) and protease ( $\mathrm{S} 09$ and A01) families, as well as terpene BGCs. The second dimension was most strongly influenced by CAZyme (GH145, CBM3, GH6, GH11, PL26, CBM60, GH7,
AA12, AA9, CBM2, GH16, CBM6, CBM87 and CE18), protease (S01, M14 and M36) families, as well as the indole and T3PKS BGC types.

The Botryosphaeriaceae were distributed mainly along the first dimension of the PCA and clustered into three groups. Eutiarosporella spp. clustered at the lower ranges of the first dimension ( $\mathrm{x}$-axis) followed by clusters accomodating the Diplodia species towards the middle ranges and the other genera of Botryosphaeriaceae clustered at the high ranges of the $\mathrm{x}$-axis. The Botryosphaeriaceae clustered along a relatively narrow range along the second dimension (y-axis) compared to the other Dothideomycetes. The clustering of the other Dothideomycetes along the $\mathrm{x}$-axis was correlated to their clustering on the $y$-axis: taxa towards the higher end of the $\mathrm{x}$-axis also occurred towards the higher end of the $\mathrm{y}$ axis. The clustering of taxa did not correspond to their nutritional lifestyle, but their taxonomic placement was reflected in their clustering.

\section{Genome architecture}

Two-dimensional heatmaps of the $5^{\prime}$ and $3^{\prime}$ FIRs of the 26 Botryosphaeriaceae genomes indicated no genome compartmentalization (Fig. 5 and Additional file 4). This was evident from the unimodal gene density distributions of these genomes. Genomes of Botryosphaeria,

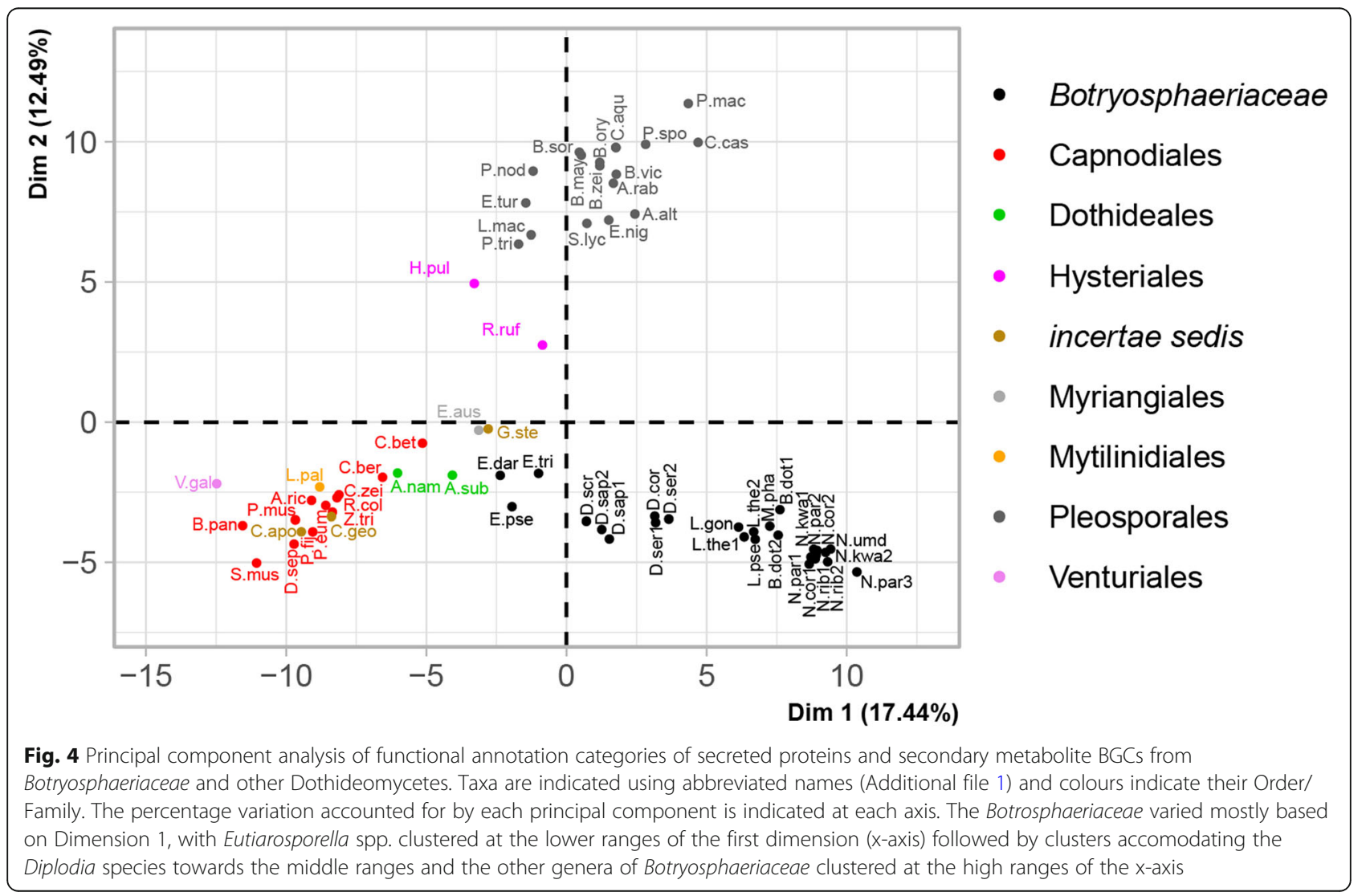




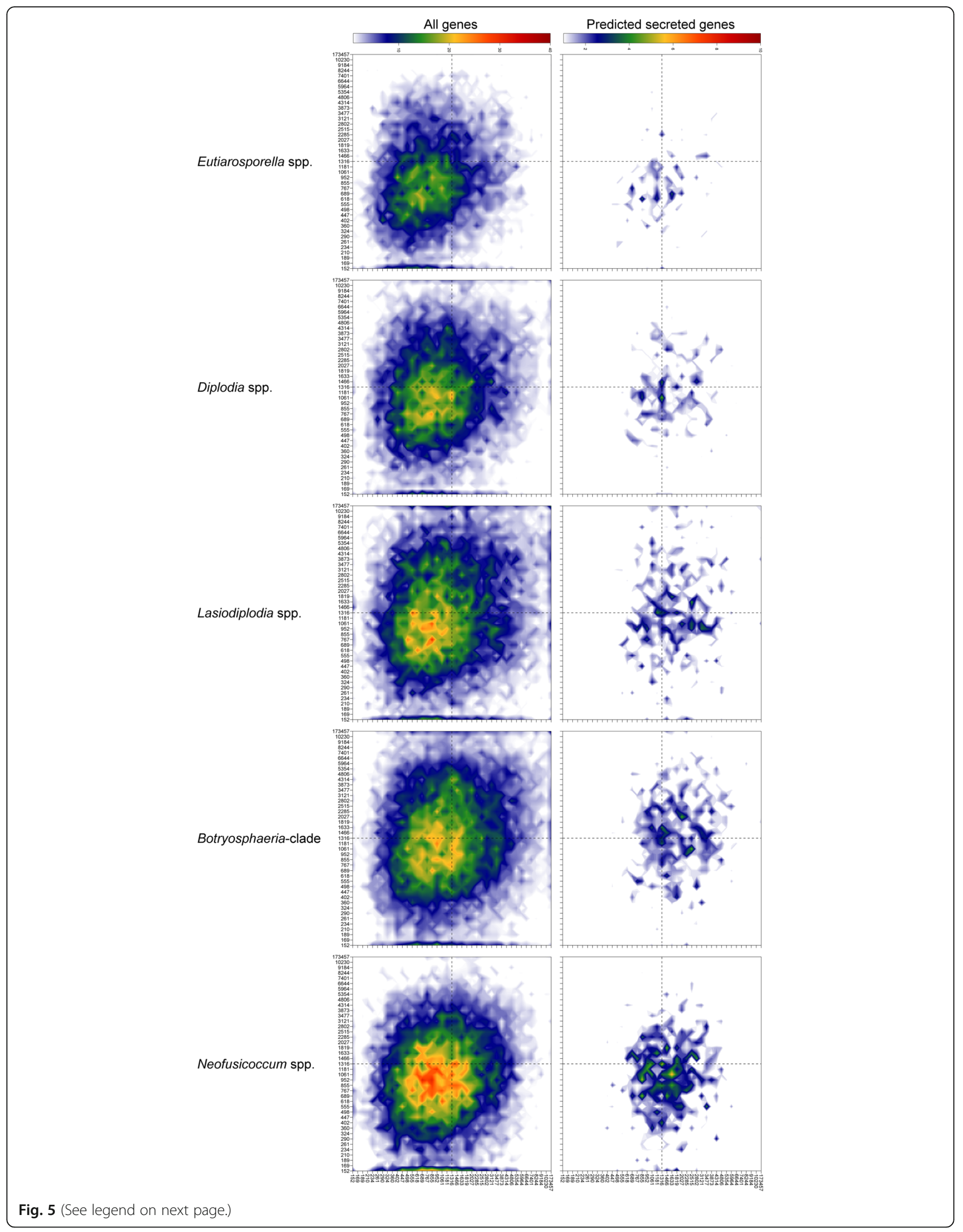


(See figure on previous page.)

Fig. 5 Gene density landscape of the genera of Botryosphaeriaceae. The two-dimensional heatmap shows the distribution of genes to gene dense or sparse regions of the genome based on their $5^{\prime}$ and $3^{\prime}$ flanking intergenic regions (FIRs). Two-dimensional heatmaps of each genus is the average across bins of all genomes in the group. The heatmaps labelled as "Botryosphaeria-clade" include the genomes of $B$. dothidea, $B$. kuwatsukai and M. phaseolina. The values on the axes are distances in base pairs and signify the upper limit of each bin. The median bin is indicated by dotted lines to assist in comparison between plots. The colours of the heatmap represents the number of genes present within each two-dimensional bin. All Botryosphaeriaceae had unimodal gene density distributions, with Eutiarosporella, Diplodia and Neofusicoccum with a greater overall gene density (smaller intergenic regions) than the other genera

Lasiodiplodia and Macrophomina had a higher proportion of genes in gene sparse regions than the other species in this family. Eutiarosporella spp., D. sapinea, D. scrobiculata and Neofusicoccum spp. had fewer genes in gene sparse regions.

The predicted secreted proteins of the Botryosphaeriaceae contained a greater number of genes in gene sparse regions than the total predicted genes (Additional file 4). The total CAZymes contained a higher proportion of genes in gene sparse regions than the total predicted genes. The secreted CAZyme gene density distribution was very similar to that of the total CAZymes. The secreted lipases and cutinases, however, occurred more frequently in gene sparse regions than the total lipases and cutinases (Additional file 4). This trend was also observed for the secreted proteases, although not as strongly. Genes associated with secondary metabolite BGCs were less prevalent in gene sparse regions.

The levels of repetitive sequences for most Botryosphaeriaceae genomes were between 3 and $8 \%$ of the total genome size (Table 5). The two Botryosphaeria spp. differed considerably in their repeat content $(3.48$ vs. $11.88 \%$ ). The genome of $M$. phaseolina also had a higher than average repeat content (16.37\%). Among the Neofusicoccum species, the genomes of $N$. parvum and $N$. umdonicola had less repetitive sequences than the other genomes of this genus. The genomes of $D$. sapinea and D. scrobiculata also contained less repetitive sequences than the other two Diplodia species.

On average, the Botryosphaeriaceae genomes had less than $10 \%$ of their genomes composed of TA rich regions (GC $<50 \%$ ) (Table 5). The genomes of B. kuwatsukai LW030101 and M. phaseolina had 18.9 and $19.8 \%$ of their genomes as TA rich regions, respectively. The genomes of Diplodia and Eutiarosporella had fewer TA rich regions (approximately 5\% of the genome) compared to the other genera. Less than $5 \%$ of genes were present in TA rich regions and secreted genes were not found to be over-represented among these genes (Additional file 4). The genomes of Diplodia and Eutiarosporella had considerably fewer genes associated with TA rich regions, than the other taxa of this family.

Analysis of the prevalence of RIP in the genomes of Botryosphaeriaceae indicated that this has occurred to varying degrees in these genomes (Table 5).
Neofusicoccum spp. had between 1.36 and $4.71 \%$ of their genome affected by RIP. The level of RIP was similar between different genomes of the same Neofusicoccum species. Neofusicoccum parvum and N. umdonicola had lower proportions of RIP affected sequences than the other species of the genus. There was a large ( $>10$-fold) difference in the level of RIP between $B$. dothidea and $B$. kuwatsukai. The genome of $M$. phaseolina had the highest (12.92\%) amount of RIP of all the Botryosphaeriaceae. Lasiodiplodia spp. had RIP levels between 0.72 and $1.18 \%$. The level of RIP in the genomes of $D$. sapinea and D. scrobiculata was lower than in D. seriata and D. corticola. The genome of E. tritici-australis had more than double the level of RIP affected regions than the other two species of the genus.

\section{Discussion}

This study represents the first large-scale comparative genomics-level consideration of all available genomes of Botryosphaeriaceae. The results showed that the included Botryosphaeriaceae genomes, especially those of Botryosphaeria, Macrophomina, Lasiodiplodia and Neofusicoccum, encode high numbers of secreted hydrolytic enzymes and secondary metabolite BGCs. This emerges due to these fungi having increased numbers of genes associated with plant interactions in their secretome. The results also indicate that the Botryosphaeriaceae are most similar to species of the Pleosporomycetidae based on secreted enzyme and secondary metabolite profiles. Botryosphaeriaceae genomes were furthermore determined not to be compartmentalized based on gene density or GC-content.

There was a strong correlation between the number of hydrolytic enzymes and secondary metabolite BGCs, and the genome size and gene number of the Botryosphaeriaceae considered in this study. This correlation between genome size and gene number has generally not been seen in other fungi $[4,11,80]$, because transposable elements and repetitive DNA vary significantly among species [11]. A recent comparison of Dothideomycetes genomes [81] also showed that genome size and gene number were not correlated to the abundance of functional annotation classes; neither to the lifestyle or phylogenetic placement of a species. 
Table 5 Summary of genomic architecture features of Botryosphaeriaceae genomes

\begin{tabular}{|c|c|c|c|c|c|c|c|c|c|c|}
\hline & $\begin{array}{l}\text { Genome } \\
\text { size }(\mathrm{Mb})\end{array}$ & $\begin{array}{l}\text { Repetitive } \\
\text { sequences } \\
\text { (bp) }\end{array}$ & $\begin{array}{l}\% \text { of } \\
\text { repetitive } \\
\text { sequences }\end{array}$ & $\begin{array}{l}\text { Genome } \\
\text { GC \% }\end{array}$ & $\begin{array}{l}\% \text { genome } \\
\text { that is GC } \\
\text { rich }(>50 \%)\end{array}$ & $\begin{array}{l}\text { Genes in } \\
\text { TA rich } \\
\text { regions }\end{array}$ & $\begin{array}{l}\text { Secreted } \\
\text { genes in TA } \\
\text { rich regions }\end{array}$ & $\begin{array}{l}\text { \% } \\
\text { genome } \\
\text { affected } \\
\text { by RIP } \\
\end{array}$ & $\begin{array}{l}\text { Number } \\
\text { of } \\
\text { LRARs }\end{array}$ & $\begin{array}{l}\text { Total size } \\
\text { (bp) of all } \\
\text { LRARs }\end{array}$ \\
\hline $\begin{array}{l}\text { Eutiarosporella } \\
\text { darliae } 2 \mathrm{G} 6\end{array}$ & 27.27 & $1,415,283$ & 5.19 & 61 & 98.3 & 3 & 0 & 0.91 & 4 & 32,276 \\
\hline $\begin{array}{l}\text { E. pseudodarliae } \\
\text { V4B6 }\end{array}$ & 26.74 & $1,290,421$ & 4.83 & 61.53 & 98.6 & 7 & 0 & 0.4 & 0 & 0 \\
\hline $\begin{array}{l}\text { E. tritici-australis } \\
153\end{array}$ & 26.59 & $1,544,103$ & 5.81 & 61.66 & 97.3 & 0 & 0 & 2.54 & 14 & 95,508 \\
\hline $\begin{array}{l}\text { Diplodia sapinea } \\
\text { CBS117911 }\end{array}$ & 36.05 & $1,344,948$ & 3.73 & 56.84 & 95 & 73 & 4 & 1.12 & 2 & 9500 \\
\hline $\begin{array}{l}\text { D. sapinea } \\
\text { CBS138184 }\end{array}$ & 35.24 & $1,305,464$ & 3.7 & 56.73 & 94.7 & 68 & 6 & 0.96 & 2 & 12,500 \\
\hline $\begin{array}{l}\text { D. scrobiculata } \\
\text { CBS139796 }\end{array}$ & 34.93 & $1,110,716$ & 3.18 & 57.01 & 95.6 & 63 & 6 & 0.82 & 1 & 13,000 \\
\hline $\begin{array}{l}\text { D. seriata } \\
\text { UCDDS831 }\end{array}$ & 37.27 & $1,711,911$ & 4.61 & 56.6 & 96.8 & 29 & 2 & 2.63 & 21 & 125,537 \\
\hline D. seriata F98.1 & 37.12 & $1,593,160$ & 4.27 & 48.47 & 94.5 & 51 & 1 & 1.87 & 34 & 554,000 \\
\hline $\begin{array}{l}\text { D. corticola } \\
\text { CBS112549 }\end{array}$ & 34.99 & $2,102,085$ & 6.01 & 47.92 & 94.5 & 31 & 3 & 3.39 & 42 & 690,014 \\
\hline $\begin{array}{l}\text { Lasiodiplodia } \\
\text { theobromae } \\
\text { CBS164.96 }\end{array}$ & 42.97 & $1,498,597$ & 3.49 & 54.74 & 89.9 & 354 & 32 & 0.72 & 3 & 59,500 \\
\hline $\begin{array}{l}\text { L. theobromae } \\
\text { CSS01 }\end{array}$ & 43.28 & $1,543,231$ & 3.57 & 48.15 & 89.8 & 306 & 33 & 1.04 & 18 & 375,000 \\
\hline $\begin{array}{l}\text { L. } \\
\text { pseudotheobromae } \\
\text { CBS116459 }\end{array}$ & 43.01 & $1,402,977$ & 3.26 & 54.66 & 89.2 & 377 & 36 & 0.92 & 12 & 375,000 \\
\hline $\begin{array}{l}\text { L. gonubiensis } \\
\text { CBS115812 }\end{array}$ & 41.14 & $1,330,240$ & 3.23 & 54.72 & 92.1 & 223 & 24 & 1.18 & 12 & 345,500 \\
\hline $\begin{array}{l}\text { Botryosphaeria } \\
\text { dothidea CMW8000 }\end{array}$ & 43.5 & $1,515,197$ & 3.48 & 54.3 & 89.8 & 385 & 53 & 0.88 & 1 & 5000 \\
\hline $\begin{array}{l}\text { B. kuwatsukai } \\
\text { LW030101 }\end{array}$ & 47.39 & $5,628,118$ & 11.88 & 53.09 & 81.1 & 406 & 41 & 9.65 & 170 & $1,387,657$ \\
\hline $\begin{array}{l}\text { Macrophomina } \\
\text { phaseolina MS6 }\end{array}$ & 48.88 & $8,000,688$ & 16.37 & 52.33 & 80.2 & 228 & 23 & 12.92 & 172 & $2,658,966$ \\
\hline $\begin{array}{l}\text { Neofusicoccum } \\
\text { cordaticola } \\
\text { CBS123634 }\end{array}$ & 45.71 & $3,594,350$ & 7.86 & 54.9 & 86.5 & 566 & 54 & 3.7 & 105 & $1,071,347$ \\
\hline $\begin{array}{l}\text { N. cordaticola } \\
\text { CBS123638 }\end{array}$ & 43.56 & $3,614,552$ & 8.3 & 55.92 & 88.7 & 393 & 40 & 3.99 & 47 & 324,966 \\
\hline $\begin{array}{l}N . \\
\text { kwambonambiense } \\
\text { CBS123639 }\end{array}$ & 44.17 & $3,369,216$ & 7.62 & 55.92 & 89.1 & 408 & 40 & 2.75 & 64 & 693,395 \\
\hline $\begin{array}{l}N . \\
\text { kwambonambiense } \\
\text { CBS123642 }\end{array}$ & 44.21 & $3,592,960$ & 8.13 & 56.04 & 89.2 & 459 & 49 & 2.35 & 56 & 554,628 \\
\hline $\begin{array}{l}\text { N. parvum } \\
\text { CMW9080 }\end{array}$ & 41.41 & $1,944,617$ & 4.7 & 56.54 & 91.3 & 406 & 40 & 1.36 & 11 & 63,557 \\
\hline $\begin{array}{l}\text { N. parvum } \\
\text { CBS123649 }\end{array}$ & 42.16 & $2,032,314$ & 4.82 & 56.06 & 91.8 & 360 & 36 & 1.65 & 14 & 88,222 \\
\hline N. parvum UCRNP2 & 42.52 & $2,167,908$ & 5.1 & 56.76 & 91.4 & 407 & 35 & 1.59 & 11 & 72,874 \\
\hline N. ribis CBS115475 & 43.18 & $3,241,261$ & 7.51 & 55.71 & 89.6 & 379 & 38 & 4.52 & 79 & 911,957 \\
\hline N. ribis CBS121.26 & 43.12 & $3,171,232$ & 7.35 & 55.88 & 89.1 & 423 & 51 & 4.71 & 25 & 153,638 \\
\hline
\end{tabular}


Table 5 Summary of genomic architecture features of Botryosphaeriaceae genomes (Continued)

\begin{tabular}{|c|c|c|c|c|c|c|c|c|c|c|}
\hline & $\begin{array}{l}\text { Genome } \\
\text { size }(\mathrm{Mb})\end{array}$ & $\begin{array}{l}\text { Repetitive } \\
\text { sequences } \\
\text { (bp) }\end{array}$ & $\begin{array}{l}\% \text { of } \\
\text { repetitive } \\
\text { sequences }\end{array}$ & $\begin{array}{l}\text { Genome } \\
\text { GC \% }\end{array}$ & $\begin{array}{l}\text { \% genome } \\
\text { that is GC } \\
\text { rich (>50\%) }\end{array}$ & $\begin{array}{l}\text { Genes in } \\
\text { TA rich } \\
\text { regions }\end{array}$ & $\begin{array}{l}\text { Secreted } \\
\text { genes in TA } \\
\text { rich regions }\end{array}$ & $\begin{array}{l}\text { \% } \\
\text { genome } \\
\text { affected } \\
\text { by RIP }\end{array}$ & $\begin{array}{l}\text { Number } \\
\text { of } \\
\text { LRARs }\end{array}$ & $\begin{array}{l}\text { Total size } \\
\text { (bp) of all } \\
\text { LRARs }\end{array}$ \\
\hline $\begin{array}{l}\text { N. umdonicola } \\
\text { CBS123644 }\end{array}$ & 42.29 & $2,237,372$ & 5.29 & 56.51 & 91.6 & 415 & 48 & 1.38 & 11 & 76,232 \\
\hline
\end{tabular}

The genomes of Botryosphaeria, Macrophomina, Lasiodiplodia and Neofusicoccum had abundant secreted hydrolytic enzyme and secondary metabolite BGCs. This is a pattern that is most similar to prominent necrotrophic plant pathogens (A. alternata, C. casiicola), saprobes (C. aquaticus, $P$. sporulosa) and the endophyte/ latent pathogen $P$. macrospinosa in the Pleosporales. The pattern was consistent with reports that necrotrophic pathogens tend to have higher numbers of hydrolytic enzymes and secondary metabolite toxins than biotrophs and symbiotic fungi [7, 82]. An abundance of secreted hydrolytic enzymes and secondary metabolite BGCs found in the Botryosphaeriaceae is also similar to that of other species of woody endophytes. Studies on such endophytic species have shown that they have similar or higher amounts of various secreted enzymes (notably plant cell wall degrading enzymes) or secondary metabolites than closely related plant pathogenic species [41-44]. The specific gene families that are enriched, however, differ among endophytic lineages, due to the evolutionary independent origins of endophytism [41-44]. It has furthermore been noted that fungi with dual lifestyles (e.g. fungi with endophytic and pathogenic phase) have large numbers of CAZymes [83, 84], however, few studies have investigated this. These observations also emerging from the present study are consistent with the known dual-lifestyle of Botryosphaeriaceae as latent pathogens.

The Botryosphaeriaceae genomes were rich in CAZymes, especially those involved in plant cell wall degradation (PCWD), although at lower numbers in the genomes of Diplodia and Eutiarosporella species. CAZymes involved in the degradation of cellulose, hemicellulose and pectin were present in all Botryosphaeriaceae. The genomes of Botryosphaeria, Macrophomina, Lasiodiplodia and Neofusicoccum were particularly rich in CAZyme families involved in cell wall degradation. Specifically, CAZymes involved in plant, general and fungal cell wall degradation $[4,85,86]$ were abundant in the genomes of the above-mentioned genera.

The Botryosphaeriaceae secretomes were rich in CAZyme families involved in the recognition of cellulose (CBM1) and chitin (CBM18). Although carbohydratebinding domains have no catalytic activity of their own they play important roles in substrate recognition and binding of other CAZymes $[87,88]$, they are also involved in the protection of fungal cell walls from degradation by host enzymes and prevention of host detection [1, 89]. High numbers of secreted CAZymes involved with PCWD have also been found in previous studies of $N$. parvum and D. seriata [31, 32] and in other, especially necrotrophic, Dothideomycetes $[62,63$, $66,70,85]$. The abundance of these CAZyme families in some genera of Botryosphaeriaceae suggests that cell wall degradation plays an important role in the biology of these fungi.

Several important CAZyme families that are common among Dothideomycetes were absent from all the Botryosphaeriaceae genomes, i.e. Acetyl xylan esterase (CE3) [90], Pyrroloquinoline quinone-dependent oxidoreductase (AA12) [91], endo- $\alpha-1,4$-polygalactosaminidase (GH114) [92] and $\alpha$-L-arabinofuranosidase $/ \beta$ xylosidase (GH54) [93]. The absence of these CAZyme families in the Botryosphaeriaceae does not necessarily indicate a gap in the metabolic repertoire of these fungi because a large degree of functional redundancy is commonly seen in fungal CAZyme repertoires [94-96]. Interestingly, some of the CAZyme families that can functionally compensate for the absence of the abovementioned CAZyme families are those that were found to be among the most abundant secreted CAZyme families of the Botryosphaeriaceae (e.g. CE16, AA3, AA7, GH15 and GH3).

The Botryosphaeriaceae were rich in secreted serine-, metallo- and aspartic-proteases. Protease families (A01, S08, S09, S10) that were previously identified as the most common secreted proteases among Dothideomycetes [4] were also the most abundant in the Botryosphaeriaceae. Secreted proteases play important roles in nutrient acquisition, signalling and degradation of plant defences [3, 97-99]. Although secreted proteases are abundant in several necrotrophic pathogens, e.g. Corynespora cassiicola [66] and several Colletotrichum spp. [100], no patterns between nutritional lifestyle and the abundance of secreted proteases could be distinguished. The precise function of most of these proteases in the Botryosphaeriaceae are unknown and their role during infection and disease expression remains to be determined.

A lower abundance and diversity of secreted protease inhibitors of the Botryosphaeriaceae suggests a reduced capacity and/or need for extracellular enzyme inhibition. 
Plant pathogenic fungi secrete protease inhibitors to inhibit plant proteases involved in defence responses [101] and several protease inhibitors are known virulence factors, e.g. avr2 of Cladosporium fulvum [102, 103] and Pit2 of Ustilago maydis [104]. However, the exact role of many fungal protease inhibitors, such as those secreted by the Botryosphaeriaceae and Dothideomycetes, remains unknown [105].

Botryosphaeriaceae, especially species of Botryosphaeria, Macrophomina, Lasiodiplodia and Neofusicoccum possessed high numbers of secreted lipases. Three lipase families were present in high numbers in the secretomes of the Dothideomycetes, i.e. Candida rugosa lipase-like (abH03), cutinases (abH36 and CE5) and Filamentous fungi lipases (abH23). The Botryosphaericeae genomes were rich in secreted enzymes for these three families. Lipases and cutinases are important for fungal penetration of host tissue $[6,106]$, growth and adhesion [107, 108] and manipulation of host defences [5]. The abundance of these secreted lipases and cutinases emphasises their potentially important role during the infection process in the Botryosphaeriaceae.

The genomes of Botryosphaeria, Macrophomina, Lasiodiplodia and Neofusicoccum contained many BGCs, especially t1PKS, NRPS, NRPS-like and TS type clusters. The products produced by most of these clusters are unknown, however, the products of some clusters could be determined. These compounds included melanin, phytotoxins (ACT-Toxin II, (-)-Mellein), siderophores (dimethylcoprogen) and antioxidants (pyranonigrin E). Many phytotoxic secondary metabolites have been identified in the Botryosphaeriaceae [109-114]. Of these, the most commonly identified phytotoxic compounds are mellein and its derivatives $[115,116]$. The presence of a predicted ACT-toxin producing gene cluster in the Botryosphaeriaceae is interesting as it is a host selective toxin from citrus infecting A. alternata [117]. This toxin is part of the Epoxy-decatrienoic acid (EDA) family, however, neither this type of toxin or any in this family has been isolated from the Botryosphaeriaceae. The ability to produce secondary metabolite toxins have been associated with pathogenic fungi's lifestyle, host range and virulence $[4,118$, 119]. Many plant pathogenic fungi have large numbers of secondary metabolite BGCs, e.g. Bipolaris spp. [120], Corynespora cassiicola [66], Colletotrichum spp. [100] and Pyrenophora teres [4], but so also do fungi with other lifestyles such as the saprobic Annulohypoxylon stygium [121], Hysterium pulicare, and Rhytidhysteron rufulum [4]. Despite the observation that the total abundance of secondary metabolite BGCs does not predict lifestyle, several fungal toxins are able to modulate a fungal species' host range or virulence, e.g. the AF-toxin of A. alternata [118], the Hybrid-1,2 and 3 genes of Eutiarosporella darliae and E. pseudodarliae [27] and the HC-toxins of Bipolaris zeicola [122].
The Botryosphaeriaceae genera were shown to possess non-compartmentalized genomes. These species were characterized as having moderate to high \% GC, RIPaffected genomes with low amounts of repetitive DNA, a slight preferential localization of secreted genes to gene sparse regions and no preferential localization of secreted genes to TA rich regions. Most Dothideomycetes do not have compartmentalized genomes, but several important pathogenic species (e.g. L. maculans and Pseudocercospora spp.), have genomes with high levels of repetitive DNA (often transposable elements) [12, 57] enriched for fast-evolving genes related to pathogenicity or virulence [57, 123, 124]. However, not all rapidly evolving fungal phytopathogens have this characteristic 'two-speed' genome architecture [13]. Where 'two-speed' genomes rely on the action of leaky RIP to generate variation for selection to act on, 'one-speed' genomes of fast-evolving plant pathogens rely on the absence of RIP that allows gene duplication/copy number variation to generate variation [13]. The Botryosphaeriaceae are not like those species with 'two-speed' genomes as they don't have compartmentalized genomes, but RIP is also not completely absent as seen in species with 'one-speed' fast-evolving genomes.

\section{Conclusions}

This study is the first large-scale comparative genomics study to consider all available genomes of Botryosphaeriaceae. It has illustrated large variability in the secreted hydrolytic enzyme and secondary metabolite biosynthetic repertoire between genera of this family. Most importantly, we have demonstrated similarities between the Botryosphaeriaceae and necrotrophic plant pathogens and endophytes of woody plants, emphasising their role as latent pathogens. This study highlights the importance of these genes in the infection biology of Botryosphaeriaceae species and their interaction with plant hosts. This knowledge will be useful in future studies aimed at understanding the mechanisms of endophytic infections and how these transition to a pathogenic state. The results should also help to better understand the genetic factors involved in determining the complex question of host range in the Botryosphaeriaceae.

\section{Materials and methods}

\section{Genomic data}

All available, published Botryosphaeriaceae genomes were retrieved from public databases (NCBI and JGI). Additionally, we sequenced and assembled 12 genomes representing three Lasiodiplodia spp. and five Neofusicoccum spp. (Table 1). To standardize protein annotations for downstream application, all of the above Botryosphaeriaceae genomes were annotated using the same pipeline described below. Additionally, the 
genomes and protein annotations of 41 Dothideomycetes and Aspergillus nidulans (Eurotiales), which had both genomic sequences and annotated protein sequences available on NCBI, were retrieved (Table 1). These genomes were used for comparative purposes in the phylogenomic analyses, hydrolytic enzyme and secondary metabolite BGC analyses and in the statistical clustering analyses, described below.

\section{DNA extraction, genome sequencing and assembly}

Cultures of three Lasiodiplodia and five Neofusicoccum species (Table 1) were inoculated onto cellophane covered $2 \%$ malt extract agar (MEA; Biolab, Merck) and incubated at $22^{\circ} \mathrm{C}$. After 5 days, mycelium was harvested from the surface of the cellophane using a sterile scalpel and DNA was extracted using a modified phenol/chloroform protocol, that included the addition of potassium acetate to precipate protein. Mycelium was ground to a fine powder using liquid nitrogen and mortar and pestle. Approximately $500 \mathrm{mg}$ of ground mycelium was used for DNA extraction. To the ground mycelia, $18 \mathrm{ml}$ of a 200 $\mathrm{mM}$ Tris- $\mathrm{HCl}$ (pH 8.0), $150 \mathrm{mM} \mathrm{NaCl}, 25 \mathrm{mM}$ EDTA (Ethylenediaminetetraacetic acid, $\mathrm{pH}$ 8.0) and 0.5\% SDS (Sodium dodecyl sulfate) solution and $125 \mu \mathrm{l}$ of $20 \mathrm{mg} /$ $\mathrm{ml}$ Proteinase $\mathrm{K}$ was added and incubated at $60^{\circ} \mathrm{C}$ for 2 h. This was followed by addition of $6 \mathrm{ml}$ of $5 \mathrm{M}$ potassium acetate and $30 \mathrm{~min}$ incubation at $0^{\circ} \mathrm{C}$. Samples were then centrifuged at $5000 \mathrm{~g}$ for $20 \mathrm{~min}$. The aqueous phase was kept and $24 \mathrm{ml}$ of a 1:1 phenol:chloroform solution was added; samples were then centrifuged as above. Two chloroform washes were performed on the aqueous phase, followed by addition of $100 \mu \mathrm{l}$ of $10 \mathrm{mg} /$ $\mathrm{ml}$ Rnase A and incubated for $2 \mathrm{~h}$. DNA was precipitated using one volume isopropanol and centrifuged for $30 \mathrm{~min}$. The pellet was cleaned with two $70 \%$ ethanol washes and resuspended in $1 \mathrm{x}$ Tris-EDTA buffer.

The extracted DNA was used for paired-end sequencing (average fragment size of $500 \mathrm{bp}$ ). All samples were sequenced on an Illumina HiSeq 2500 platform, except for $N$. parvum (isolate CMW9080) that was sequenced on a Miseq platform. The quality of the resulting reads was assessed using FastQC 0.10.1 [125] and low quality and short reads were trimmed or discarded using Trimmomatic 0.30 [126]. De novo genome assembly was performed by Velvet 1.2.10 [127] and Velvetoptimiser 2.2.5 [128]. Paired-end reads were used to scaffold the assembly and insert size statistics were determined by Velvet for each genome assembly. Genome assembly summary statistics were calculated with the AssemblyStatsWrapper tool of BBtools 38.00 [129].

\section{Genome annotation}

The twelve sequenced genomes described above, as well as the fourteen Botryosphaeriaceae genomes retrieved from public databases, were annotated as follows: Custom repeat libraries were constructed for each genome assembly using RepeatModeler 1.0.10 [130]. BRAKER 1.10 [131] was used to create trained GeneMark-ET 4.29 [132] and AUGUSTUS 3.2.3 [133] profiles using previously published $N$. parvum transcriptome data (SRR3992643 and SRR3992649) [31]. Genomes were annotated through the MAKER2 2.31.8 [134] pipeline using the custom repeat libraries and the BRAKER trained GeneMark-ET 4.29 and AUGUSTUS profiles. Genomes and genome annotations were assessed for completeness with BUSCO 4.0.5 [135] using the Ascomycota ortholog library (Creation date 2020-09-10, 1706 core orthologous genes). The annotations for six Botryosphaeriaceae genomes available on public databases prior to this study were also assessed using BUSCO and compared to those of the annotations generated in this study.

\section{Phylogenomic analyses}

To illustrate the relationships between species and genera of the Botryosphaeriaceae, as well as the relationship of this family to the rest of the Dothideomycetes, a robust phylogeny was created from the genome data. Single copy core orthologous genes were identified from individual genomes (Table 1) using BUSCO (as described above). The BUSCO genes present in all taxa (207 genes) were selected for further analysis. Each orthogroup was aligned using MAFFT 7.407 [136] before being concatenated into a single matrix. RAxML 8.2.4 [137] was used to perform maximum likelihood phylogenetic inference using the PROTGAMMAAUTO option and a thousand bootstrap replicates were performed. Trees were rooted using sequences from $A s$ pergillus nidulans.

\section{Functional annotation}

The genome annotation data for the Botryosphaeriaceae, the other Dothideomycetes and the outgroup A. nidulans were used to perform functional annotation for hydrolytic enzymes and secondary metabolite BGCs. CAZymes were predicted by searching the total predicted proteins of each genome against the CAZy database [138] using dbCAN2 (HMMdb release v9.0) [139]. Only those CAZyme predictions supported by two or more tools (HMMR, DIAMOND, Hotpep) were retained. Proteases and protease inhibitors were predicted by subjecting the predicted protein sequences to a BLASTP [140] search against the MEROPS protease database 12.0 [141] using a cut off E-value of 1E-04. Lipases and cutinases were predicted by searching protein sequences against lipase and cutinase hidden Markov model (HMM) profiles retrieved from the Lipase Engineering Database v 3.0 [142] using HMMER 3.1b2 [143]. 
Secondary metabolite BGCs were identified from all annotated genomes using AntiSMASH v5.1.1 [144].

The total predicted proteins were also analyzed for the presence of signal peptides, involved in protein secretion. Phobius 1.01 [145] and SignalP 4.1 [146] were used to assess the presence of signal peptides and TMHMM 2.0 [147] was used to determine if any transmembrane regions occurred within these proteins. Only proteins with a signal peptide predicted by both Phobius and SignalP, as well as no transmembrane domains outside of the signal peptide predicted by both Phobius and TMHMM were regarded here as predicted secreted proteins.

Statistical analyses were performed using the total number of annotations, as well as the number of each enzyme class/secondary metabolite BGC type. Statistical tests were done comparing the genera of the Botrysphaeriaceae, but also for comparisons between Dothideomycetidae, Pleosporomycetidae and Botryosphaeriaceae. Due to the small number of representative genomes for Botryosphaeria (2) and Macrophomina (1) and their close phylogenetic placement, they were combined in a single group (i.e. Botryosphaeria-clade) for the purpose of statistical analyses. We further also included Cenococcum geophilum, Coniosporium apollinis and Glonium stellatum in the Pleosporomycetidae, based on their phylogenetic placement (Fig. 1).

We calculated pairwise Pearsons correlation coefficients [148] in order to test whether genome size, the number of predicted genes or any of the functional annotation categories were correlated. The Shapiro-Wilk test [149] was performed in order to test for a normal distribution using the byf.shapiro function of the RVAideMemoire R-package [150]. Pairwise comparisons to test for significant differences were done using onetailed Wilcoxon rank-sum tests [151] in $\mathrm{R}$ using the pairwise.wilcox.test function of the $\mathrm{R}$ stats package [152] with either the 'greater' or 'less' alternative hypothesis options. This is a non-parametric test to determine whether two independent sets of values have the same distribution. Unlike the t-test, the Wilcoxon rank sum test does not assume a normal distribution [153] and thus was better suited to our data. These same tests as above were done using the total number of predicted, as well as the number of secreted genes, associated with hydrolytic enzyme families to test if specific CAZyme, protease or lipase families within the secretomes of the Dothideomycetidae, Pleosporomycetidae and Botryosphaeriaceae were significantly different.

\section{Analysis of gene family evolution}

CAFE (Computational Analysis of gene Family Evolution) v4.2 [154] was used to study the evolution of gene family size in the hydrolytic enzymes and secondary metabolite BGCs. To this end, the phylogeny described above was converted to an ultrametric tree using r8s v1.81 [155]. This was then calibrated by fixing the age of the Botrosphaeriaceae to 61 million years [79] and constraining the age of the Dothideomycetes to 303-357 million years [156]. Gene family sizes for the total predicted CAZymes, proteases, lipases and secondary metabolite BGCs (Additional file 1) were used as input for the CAFE analyses. CAFE was run using separate lambda (birth) and mu (death) rate parameters. Additionally, two separate rate classes were allowed in that the rate parameters were calculated independently for the Botryosphaeriaceae and the remaining Dothideomycete taxa. CAFE was run using a $P$-value cutoff of 0.01 and Viterbi $P$-values were calculated to significant expansions/contractions across branches.

\section{Hierarchical clustering and principal component analysis}

Hierarchical clustering was done to determine the similarity between taxa based on the secreted hydrolytic enzyme classes and secondary metabolite BGC types. The heatmap.2 function of the gplots [157] $\mathrm{R}$ package was used to perform the analysis. Additionally, principal component analysis (PCA) was performed using the same functional annotations as used in the hierarchical clustering, with the exception that for CAZymes and proteases the number of genes associated with each family (e.g AA1, A01) was used instead of those of each class (e.g AA, Aspartic). The FactoMineR [158] R package was used to perform the analysis and Factoshiny [159] was used to generate PCA plots.

\section{Genome architecture}

Gene densities were analyzed for each Botryosphaeriaceae genome to assess the level of genome compartmentalization. Intergenic distances were used as a measure of gene density, by considering the $5^{\prime}$ and $3^{\prime}$ flanking intergenic regions (FIRs) of each gene. FIR lengths were used for two-dimensional data binning to construct gene density heat maps [160] using $R$ [152]. Possible differences in the gene density distributions between the total and secreted CAZymes, proteases and lipases were also considered. We compared the relative amounts (i.e. the percentage) of these genes located in gene-sparse regions. In this case, gene sparse regions were defined as genes with both $5^{\prime}$ and $3^{\prime}$ FIRs larger than $1500 \mathrm{bp}$, as previously used by $\mathrm{S}$ Raffaele and $\mathrm{S}$ Kamoun [11].

The repeat contents of the Botryosphaeriaceae genomes were determined using RepeatMasker [161] with custom repeat libraries created by RepeatModeler. The presence of TA rich regions and the genes present therein were determined using OcculterCut [124]. Specifically, the numbers of the total secreted genes, the 
secreted CAZymes, proteases and lipases, as well as the number of secondary metabolite BGCs associated with TA rich regions were determined. The occurrence of RIP, including large regions affected by RIP (LRARs), was determined in each genome using TheRIPper [162].

\section{Supplementary Information}

The online version contains supplementary material available at https://doi. org/10.1186/s12864-021-07902-w.

\section{Additional file 1. \\ Additional file 2. \\ Additional file 3 . \\ Additional file 4.}

\section{Acknowledgements}

We are grateful to the University of Pretoria, The Department of Science and Technology (DST)/National Research Foundation (NRF) Centre of Excellence in Tree Health Biotechnology and members of the Tree Protection Cooperative Program for financial support of this study. The authors acknowledge the Centre for Bioinformatics and Computational Biology, University of Pretoria and the Centre for High Performance Computing (CHPC), South Africa for providing computational resources to this research project. Lastly, our sincere thanks to Alisa Postma for her guidance during the genome assembly and annotation process and to Dr. Tuan Duong for his critical comments on this manuscript.

\section{Authors' contributions}

BS and MJW were supervisors for the doctoral research by JHN. All authors contributed to the study conception, data interpretation and the revision of the manuscript. JHN performed the laboratory work, data analyses and visualizations, and wrote the draft manuscript. All authors read and approved the final manuscript.

\section{Funding}

The South African National Research Foundation (NRF) funded the Doctoral research of the first author. This project was financed by the University of Pretoria, the Department of Science and Innovation (DSI)/National Research Foundation (NRF) Centre of Excellence in Tree Health Biotechnology. The Grant holders acknowledge that opinions, findings and conclusions or recommendations expressed in any publication generated by NRF-supported research are that of the author(s) and that the NRF accepts no liability whatsoever in this regard.

\section{Availability of data and materials}

All data generated or analysed during this study are included in this published article (and its supplementary information files). Genomic data used in this study (Table 1) are available from NCBI (https://www.ncbi.nlm. nih.gov/genome) and the JGI Genome Portal (http://genome.jgi.doe.gov). Raw sequencing reads of the de novo genomes described in this study linked to Bioproject PRJNA497969 (Biosample Accessions SAMN10319569SAMN10319580) have been deposited to the Sequence Read Archive (SRA, https://www.ncbi.nlm.nih.gov/sra) database and are awaiting accession numbers.

\section{Declarations}

Ethics approval and consent to participate

Not applicable.

\section{Consent for publication}

Not applicable.

\section{Competing interests}

The authors declare that they have no competing interests.
Received: 26 January 2021 Accepted: 30 June 2021

Published online: 04 August 2021

\section{References}

1. De Jonge $\mathrm{R}$, Thomma BPHJ. Fungal LysM effectors: extinguishers of host immunity? Trends Microbiol. 2009;17(4):151-7.

2. Jia Y, McAdams SA, Bryan GT, Hershey HP, Valent B. Direct interaction of resistance gene and avirulence gene products confers rice blast resistance EMBO J. 2000;19(15):4004-14. https://doi.org/10.1093/emboj/19.15.4004.

3. Carlile AJ, Bindschedler LV, Bailey AM, Bowyer P, Clarkson JM, Cooper RM. Characterization of SNP1, a cell wall-degrading trypsin, produced during infection by Stagonospora nodorum. Mol Plant-Microbe Interact. 2000;13(5): 538-50.

4. Ohm RA, Feau N, Henrissat B, Schoch CL, Horwitz BA, Barry KW, et al. Diverse lifestyles and strategies of plant pathogenesis encoded in the genomes of eighteen Dothideomycetes fungi. PLoS Pathog. 2012;8(12): e1003037.

5. Christensen SA, Kolomiets MV. The lipid language of plant-fungal interactions. Fungal Genet Biol. 2011;48(1):4-14. https://doi.org/10.1016/j. fgb.2010.05.005

6. Voigt CA, Schäfer W, Salomon S. A secreted lipase of Fusarium graminearum is a virulence factor required for infection of cereals. Plant J. 2005;42(3):36475. https://doi.org/10.1111/j.1365-313X.2005.02377.X.

7. Zhao Z, Liu H, Wang C, Xu J-R. Correction: comparative analysis of fungal genomes reveals different plant cell wall degrading capacity in fungi. BMC Genomics. 2014;15(1):6.

8. Keller NP, Turner G, Bennett JW. Fungal secondary metabolism—from biochemistry to genomics. Nat Rev Microbiol. 2005;3(12):937-47.

9. Howlett BJ. Secondary metabolite toxins and nutrition of plant pathogenic fungi. Curr Opin Plant Biol. 2006:9(4):371-5.

10. Dong S, Raffaele S, Kamoun S. The two-speed genomes of filamentous pathogens: waltz with plants. Curr Opin Genet Dev. 2015;35:57-65. https:// doi.org/10.1016/j.gde.2015.09.001.

11. Raffaele S, Kamoun S. Genome evolution in filamentous plant pathogens: why bigger can be better. Nat Rev Microbiol. 2012;10(6):417-30. https://doi. org/10.1038/nrmicro2790.

12. Rouxel T, Grandaubert J, Hane JK, Hoede C, van de Wouw AP, Couloux A, et al. Effector diversification within compartments of the Leptosphaeria maculans genome affected by repeat-induced point mutations. Nat Commun. 2011;2(1):202. https://doi.org/10.1038/ncomms1189.

13. Frantzeskakis $L$, Kusch S, Panstruga R. The need for speed: compartmentalized genome evolution in filamentous phytopathogens. Mol Plant Pathol. 2019;20(1):3-7. https://doi.org/10.1111/mpp.12738.

14. Stukenbrock EH, Jorgensen FG, Zala M, Hansen T, McDonald BA, Schierup $\mathrm{MH}$. Whole-genome and chromosome evolution associated with host adaptation and speciation of the wheat pathogen Mycosphaerella graminicola. PLoS Genet. 2010;6(12):e1001189.

15. Möller M, Stukenbrock EH. Evolution and genome architecture in fungal plant pathogens. Nat Rev Microbiol. 2017;15(12):756.

16. Slippers B, Wingfield MJ. Botryosphaeriaceae as endophytes and latent pathogens of woody plants: diversity, ecology and impact. Fungal Biol Rev. 2007;21(2):90-106

17 Mehl JWM, Slippers B, Roux J, Wingfield MJ. Cankers and Other Diseases Caused by the Botryosphaeriaceae. In: Gonthier P, Nico G, editors. Infectious Forest Diseases: CABI; 2013:298-317.

18. Urbez-Torres JR. The status of Botryosphaeriaceae species infecting grapevines. Phytopathol Mediterr. 2011;50(4):5-45.

19. Slippers B, Smit WA, Crous PW, Coutinho TA, Wingfield BD, Wingfield MJ. Taxonomy, phylogeny and identification of Botryosphaeriaceae associated with pome and stone fruit trees in South Africa and other regions of the world. Plant Pathol. 2007;56(1):128-39.

20. Alves A, Barradas C, Phillips AJL, Correia A. Diversity of Botryosphaeriaceae species associated with conifers in Portugal. Eur J Plant Pathol. 2013;135(4): 791-804. https://doi.org/10.1007/s10658-012-0122-2.

21. Mohali S, Slippers B, Wingfield MJ. Identification of Botryosphaeriaceae from Eucalyptus, Acacia and Pinus in Venezuela. Fungal Divers. 2007;25:103-25.

22. Rodas CA, Slippers B, Gryzenhout M, Wingfield MJ. Botryosphaeriaceae associated with Eucalyptus canker diseases in Colombia. For Pathol. 2009; 39(2):110-23. https://doi.org/10.1111/j.1439-0329.2008.00569.x.

23. Jami F, Slippers B, Wingfield MJ, Gryzenhout M. Botryosphaeriaceae species overlap on four unrelated, native south African hosts. Fungal Biology. 2014; 118(2):168-79. https://doi.org/10.1016/j.funbio.2013.11.007. 
24. Marincowitz S, Groenewald JZ, Wingfield MJ, Crous PW. Species of Botryosphaeriaceae occurring on Proteaceae. Persoonia. 2008;21(1):111-8.

25. Pavlic D, Wingfield MJ, Barber P, Slippers B, Hardy GESJ, Burgess TI. Seven new species of the Botryosphaeriaceae from baobab and other native trees in Western Australia. Mycologia. 2008;100(6):851-66.

26. Jami F, Wingfield MJ, Gryzenhout M, Slippers B. Diversity of tree-infecting Botryosphaeriales on native and non-native trees in South Africa and Namibia. Australas Plant Pathol. 2017;46(6):529-45. https://doi.org/10.1007/ s13313-017-0516-X

27. Thynne E, Mead OL, Chooi Y-H, McDonald MC, Solomon PS. Acquisition and loss of secondary metabolites shaped the evolutionary path of three emerging phytopathogens of wheat. Genome Biol Evol. 2019;11(3):890-905.

28. Bihon W, Burgess T, Slippers B, Wingfield MJ, Wingfield BD. Distribution of Diplodia pinea and its genotypic diversity within asymptomatic Pinus patula trees. Australas Plant Pathol. 2011;40(5):540-8.

29. Cobos R, Barreiro C, Mateos RM, Coque J-JR. Cytoplasmic-and extracellularproteome analysis of Diplodia seriata: a phytopathogenic fungus involved in grapevine decline. Proteome Sci. 2010;8(1):46. https://doi.org/10.1186/14775956-8-46.

30. Fernandes I, Alves A, Correia A, Devreese B, Esteves AC. Secretome analysis identifies potential virulence factors of Diplodia corticola, a fungal pathogen involved in cork oak (Quercus suber) decline. Fungal Biol. 2014;118(5-6):51623. https://doi.org/10.1016/j.funbio.2014.04.006.

31. Massonnet M, Morales-Cruz A, Figueroa-Balderas R, Lawrence DP, Baumgartner K, Cantu D. Condition-dependent co-regulation of genomic clusters of virulence factors in the grapevine trunk pathogen Neofusicoccum parvum. Mol Plant Pathol. 2016;19(1):21-34.

32. Morales-Cruz A, Amrine KCH, Blanco-Ulate B, Lawrence DP, Travadon R, Rolshausen PE, et al. Distinctive expansion of gene families associated with plant cell wall degradation, secondary metabolism, and nutrient uptake in the genomes of grapevine trunk pathogens. BMC Genomics. 2015;16(1):469.

33. Blanco-Ulate B, Rolshausen P, Cantu D. Draft genome sequence of Neofusicoccum parvum isolate UCR-NP2, a fungal vascular pathogen associated with grapevine cankers. Genome announcements. 2013;1(3): e00339-13.

34. Islam MS, Haque MS, Islam MM, Emdad EM, Halim A, Hossen QMM, et al, Tools to kill: genome of one of the most destructive plant pathogenic fung Macrophomina phaseolina. BMC Genomics. 2012;13(1):493. https://doi.org/1 0.1186/1471-2164-13-493.

35. Liu Z, Lian S, Li B, Lu H, Dong X, Wang C. Draft genome sequence of Botryosphaeria dothidea, the pathogen of apple ring rot. Genome Announc. 2016:4(5):e01142-16.

36. Marsberg A, Kemler M, Jami F, Nagel JH, Postma-Smidt A, Naidoo S, et al. Botryosphaeria dothidea: a latent pathogen of global importance to woody plant health. Mol Plant Pathol. 2016;18(4):477-88. https://doi.org/10.1111/mpp.12495.

37. Robert-Siegwald G, Vallet J, Abou-Mansour E, Xu J, Rey P, Bertsch C, et al. Draft genome sequence of Diplodia seriata F98.1, a fungal species involved in grapevine trunk diseases. Genome Announc. 2017;5(14):e00061-17.

38. van der Nest MA, Bihon W, De Vos L, Naidoo K, Roodt D, Rubagotti E, et al. Draft genome sequences of Diplodia sapinea, Ceratocystis manginecans, and Ceratocystis moniliformis. IMA Fungus. 2014;5(1):135-40. https://doi.org/10. 5598/imafungus.2014.05.01.13.

39. Southworth D. Biocomplexity of plant-fungal interactions: Wiley; 2012. https://doi.org/10.1002/9781118314364

40. Schulz B, Boyle C. The endophytic continuum. Mycol Res. 2005;109(6):66186. https://doi.org/10.1017/S095375620500273X.

41. Hacquard S, Kracher B, Hiruma K, Münch PC, Garrido-Oter R, Thon MR, et al. Survival trade-offs in plant roots during colonization by closely related beneficial and pathogenic fungi. Nat Commun. 2016;7(1):1-13.

42. Schlegel $M$, Münsterkötter $M$, Güldener U, Bruggmann R, Duò A, Hainaut $M$, et al. Globally distributed root endophyte Phialocephala subalpina links pathogenic and saprophytic lifestyles. BMC Genomics. 2016;17(1):1015.

43. Xu X-H, Su Z-Z, Wang C, Kubicek CP, Feng X-X, Mao L-J, et al. The rice endophyte Harpophora oryzae genome reveals evolution from a pathogen to a mutualistic endophyte. Sci Rep. 2014;4:5783.

44. Yang Y, Liu X, Cai J, Chen Y, Li B, Guo Z, et al. Genomic characteristics and comparative genomics analysis of the endophytic fungus Sarocladium brachiariae. BMC Genomics. 2019;20(1):1-20.

45. Gazis R, Kuo A, Riley R, LaButti K, Lipzen A, Lin J, et al. The genome of Xylona heveae provides a window into fungal endophytism. Fungal Biol. 2016;120(1):26-42. https://doi.org/10.1016/j.funbio.2015.10.002.
46. Paolinelli-Alfonso M, Villalobos-Escobedo JM, Rolshausen $\mathrm{P}$, Herrera-Estrella A, Galindo-Sánchez C, López-Hernández JF, et al. Global transcriptional analysis suggests Lasiodiplodia theobromae pathogenicity factors involved in modulation of grapevine defensive response. BMC Genomics. 2016;17(1): 615. https://doi.org/10.1186/s12864-016-2952-3.

47. Gonçalves MFM, Nunes RB, Tilleman L, Van de Peer Y, Deforce D, Van Nieuwerburgh $F$, et al. Dual RNA sequencing of Vitis vinifera during Lasiodiplodia theobromae infection unveils host-pathogen interactions. Int J Mol Sci. 2019;20(23):6083. https://doi.org/10.3390/ijms20236083.

48. Ali SS, Asman A, Shao J, Balidion JF, Strem MD, Puig AS, et al. Genome and transcriptome analysis of the latent pathogen Lasiodiplodia theobromae, an emerging threat to the cacao industry. Genome. 2020;63(1):37-52.

49. Yan JY, Zhao WS, Chen Z, Xing QK, Zhang W, Chethana KW, et al. Comparative genome and transcriptome analyses reveal adaptations to opportunistic infections in woody plant degrading pathogens of Botryosphaeriaceae. DNA Res. 2017;25(1):87-102.

50. Bellée A, Comont G, Nivault A, Abou-Mansour E, Coppin C, Dufour MC, et al Life traits of four Botryosphaeriaceae species and molecular responses of different grapevine cultivars or hybrids. Plant Pathol. 2017;66(5):763-76.

51. Wang B, Liang X, Gleason ML, Zhang R, Sun G. Comparative genomics of Botryosphaeria dothidea and B. kuwatsukai, causal agents of apple ring rot, reveals both species expansion of pathogenicity-related genes and variations in virulence gene content during speciation. IMA fungus. 2018; 9(2):243-57. https://doi.org/10.5598/imafungus.2018.09.02.02.

52. Bihon W, Wingfield MJ, Slippers B, Duong TA, Wingfield BD. MAT gene idiomorphs suggest a heterothallic sexual cycle in a predominantly asexual and important pine pathogen. Fungal Genet Biol. 2014;62:55-61. https://doi. org/10.1016/j.fgb.2013.10.013.

53. Wingfield BD, Ades PK, Al-Naemi FA, Beirn LA, Bihon W, Crouch JA, et al. Draft genome sequences of Chrysoporthe austroafricana, Diplodia scrobiculata, Fusarium nygamai, Leptographium lundbergii, Limonomyces culmigenus, Stagonosporopsis tanaceti, and Thielaviopsis punctulata. IMA Fungus. 2015;6(1):233-48. https://doi.org/10.5598/imafungus.2015.06.01.15.

54. Mosier AC, Miller CS, Frischkorn KR, Ohm RA, Li Z, LaButti K, et al. Fungi contribute critical but spatially varying roles in nitrogen and carbon cycling in acid mine drainage. Front Microbiol. 2016;7:238.

55. de Jonge R, Ebert MK, Huitt-Roehl CR, Pal P, Suttle JC, Spanner RE, et al. Gene cluster conservation provides insight into cercosporin biosynthesis and extends production to the genus Colletotrichum. Proc Natl Acad Sci. 2018;115(24):E5459-66.

56. Wingfield BD, Berger DK, Steenkamp ET, Lim H-J, Duong TA, Bluhm BH, et al. Draft genome of Cercospora zeina, Fusarium pininemorale, Hawksworthiomyces lignivorus, Huntiella decipiens and Ophiostoma ips. IMA Fungus. 2017:8(2):385-96.

57. Chang T-C, Salvucci A, Crous PW, Stergiopoulos I. Comparative genomics of the Sigatoka disease complex on banana suggests a link between parallel evolutionary changes in Pseudocercospora fijiensis and Pseudocercospora eumusae and increased virulence on the banana host. PLoS Genet. 2016; 12(8):e1005904. https://doi.org/10.1371/journal.pgen.1005904.

58. McGrann GRD, Andongabo A, Sjökvist E, Trivedi U, Dussart F, Kaczmarek M, et al. The genome of the emerging barley pathogen Ramularia collo-cygni. BMC Genomics. 2016;17(1):584.

59. Goodwin SB, M'barek SB, Dhillon B, Wittenberg AH, Crane CF, Hane JK, et al. Finished genome of the fungal wheat pathogen Mycosphaerella graminicola reveals dispensome structure, chromosome plasticity, and stealth pathogenesis. PLoS Genet. 2011;7(6):e1002070. https://doi.org/10.1371/ journal.pgen.1002070.

60. Gostinčar C, Ohm RA, Kogej T, Sonjak S, Turk M, Zajc J, et al. Genome sequencing of four Aureobasidium pullulans varieties: biotechnological potential, stress tolerance, and description of new species. BMC Genomics. 2014;15(1):549.

61. Peter M, Kohler A, Ohm RA, Kuo A, Krützmann J, Morin E, et al. Ectomycorrhizal ecology is imprinted in the genome of the dominant symbiotic fungus Cenococcum geophilum. Nat Commun. 2016;7(1):12662. https://doi.org/10.1038/ncomms12662.

62. Zeiner CA, Purvine SO, Zink EM, Paša-Tolić L, Chaput DL, Haridas S, et al. Comparative analysis of secretome profiles of manganese (II)-oxidizing ascomycete fungi. PLoS One. 2016;11(7):e0157844. https://doi.org/10.1371/ journal.pone.0157844.

63. Verma S, Gazara RK, Nizam S, Parween S, Chattopadhyay D, Verma PK. Draft genome sequencing and secretome analysis of fungal phytopathogen 
Ascochyta rabiei provides insight into the necrotrophic effector repertoire. Sci Rep. 2016;6(1):24638. https://doi.org/10.1038/srep24638.

64. Condon BJ, Leng Y, Wu D, Bushley KE, Ohm RA, Otillar R, et al. Comparative genome structure, secondary metabolite, and effector coding capacity across Cochliobolus pathogens. PLoS Genet. 2013;9(1):e1003233.

65. Mondo SJ, Dannebaum RO, Kuo RC, Louie KB, Bewick AJ, LaButti K, et al. Widespread adenine N6-methylation of active genes in fungi. Nat Genet. 2017:49(6):964-8. https://doi.org/10.1038/ng.3859.

66. Lopez D, Ribeiro S, Label P, Fumanal B, Venisse J-S, Kohler A, et al. Genomewide analysis of Corynespora cassiicola leaf fall disease putative effectors. Front Microbiol. 2018;9:276.

67. Fokin M, Fleetwood D, Weir BS, Villas-Boas S. Genome sequence of the saprophytic ascomycete Epicoccum nigrum strain ICMP 19927, isolated from New Zealand. Genome Announc. 2017;5(24):e00557-17.

68. Hane JK, Lowe RGT, Solomon PS, Tan K-C, Schoch CL, Spatafora JW, et al. Dothideomycete-plant interactions illuminated by genome sequencing and EST analysis of the wheat pathogen Stagonospora nodorum. Plant Cell. 2007; 19(11):3347-68. https://doi.org/10.1105/tpc.107.052829.

69. Knapp DG, Németh JB, Barry K, Hainaut M, Henrissat B, Johnson J, et al. Comparative genomics provides insights into the lifestyle and reveals functional heterogeneity of dark septate endophytic fungi. Sci Rep. 2018; 8(1):6321. https://doi.org/10.1038/s41598-018-24686-4.

70. Manning VA, Pandelova I, Dhillon B, Wilhelm $\sqcup$, Goodwin SB, Berlin AM, et al. Comparative genomics of a plant-pathogenic fungus, Pyrenophora tritici-repentis, reveals transduplication and the impact of repeat elements on pathogenicity and population divergence. G3. 2013;3(1):41-63.

71. Franco MEE, López S, Medina R, Saparrat MCN, Balatti P. Draft genome sequence and gene annotation of Stemphylium lycopersici strain CIDEFI-216. Genome Announc. 2015;3(5):e01069-15.

72. Teixeira MM, Moreno LF, Stielow BJ, Muszewska A, Hainaut M, Gonzaga L, et al. Exploring the genomic diversity of black yeasts and relatives (Chaetothyriales, Ascomycota). Stud Mycol. 2017;86:1-28.

73. Galagan JE, Calvo SE, Cuomo C, Ma L-J, Wortman JR, Batzoglou S, et al. Sequencing of Aspergillus nidulans and comparative analysis with $a$. fumigatus and A. oryzae. Nature. 2005;438(7071):1105-15. https://doi.org/10.1 038/nature04341.

74. Zhang Y, Crous PW, Schoch CL, Bahkali AH, Guo LD, Hyde KD. A molecular, morphological and ecological re-appraisal of Venturiales-a new order of Dothideomycetes. Fungal Divers. 2011:51(1):249-77.

75. Schoch CL, Crous PW, Groenewald JZ, Boehm EWA, Burgess TI, De Gruyter J, et al. A class-wide phylogenetic assessment of Dothideomycetes. Stud Mycol. 2009;64:1-15. https://doi.org/10.3114/sim.2009.64.01.

76. Schoch CL, Shoemaker RA, Seifert KA, Hambleton S, Spatafora JW, Crous PW. A multigene phylogeny of the Dothideomycetes using four nuclear loci. Mycologia. 2006;98(6):1041-52. https:/doi.org/10.1080/15572536.2006.11832632.

77. Yang T, Groenewald JZ, Cheewangkoon R, Jami F, Abdollahzadeh J, Lombard L, et al. Families, genera, and species of Botryosphaeriales. Fungal Biol. 2017;121(4):322-46. https://doi.org/10.1016/j.funbio.2016.11.001.

78. Slippers B, Boissin E, Phillips AJL, Groenewald JZ, Lombard L, Wingfield MJ, et al. Phylogenetic lineages in the Botryosphaeriales: a systematic and evolutionary framework. Stud Mycol. 2013;76:31-49.

79. Phillips AJL, Hyde KD, Alves A, Liu J-KJ. Families in Botryosphaeriales: a phylogenetic, morphological and evolutionary perspective. Fungal Divers. 2019;94(1):1-22. https://doi.org/10.1007/s13225-018-0416-6.

80. Mohanta TK, Bae $\mathrm{H}$. The diversity of fungal genome. Biol Proced Online. 2015;17(1):8. https://doi.org/10.1186/s12575-015-0020-z.

81. Haridas S, Albert R, Binder M, Bloem J, LaButti K, Salamov A, et al. 101 Dothideomycetes genomes: a test case for predicting lifestyles and emergence of pathogens. Stud Mycol. 2020;96:141-53. https://doi.org/10.1 016/j.simyco.2020.01.003.

82. Lyu X, Shen C, Fu Y, Xie J, Jiang D, Li G, et al. Comparative genomic and transcriptional analyses of the carbohydrate-active enzymes and secretomes of phytopathogenic fungi reveal their significant roles during infection and development. Sci Rep. 2015;5(1):15565. https://doi.org/10.1038/srep15565.

83. Wang X, Zhang X, Liu L, Xiang M, Wang W, Sun X, et al. Genomic and transcriptomic analysis of the endophytic fungus Pestalotiopsis fici reveals its lifestyle and high potential for synthesis of natural products. BMC Genomics. 2015;16(1):28.

84. Queiroz CB, Santana MF. Prediction of the secretomes of endophytic and nonendophytic fungi reveals similarities in host plant infection and colonization strategies. Mycologia. 2020:1-13.
85. Zhao Z, Liu H, Wang C, Xu J-R. Comparative analysis of fungal genomes reveals different plant cell wall degrading capacity in fungi. BMC Genomics. 2013;14(1):274. https://doi.org/10.1186/1471-2164-14-274.

86. Levasseur A, Drula E, Lombard V, Coutinho PM, Henrissat B. Expansion of the enzymatic repertoire of the CAZy database to integrate auxiliary redox enzymes. Biotechnol Biofuels. 2013;6(1):41.

87. Christiansen C, Abou Hachem M, Janeček Š, Viksø-Nielsen A, Blennow A, Svensson B. The carbohydrate-binding module family 20-diversity, structure, and function. FEBS J. 2009;276(18):5006-29.

88. Boraston AB, Bolam DN, Gilbert HJ, Davies GJ. Carbohydrate-binding modules: fine-tuning polysaccharide recognition. Biochem J. 2004;382(3): 769-81. https://doi.org/10.1042/BJ20040892.

89. Marshall R, Kombrink A, Motteram J, Loza-Reyes E, Lucas J, HammondKosack K, et al. Analysis of two in planta expressed LysM effector homologues from the fungus Mycosphaerella graminicola reveals novel functional properties and varying contributions to virulence on wheat. Plant Physiol. 2011:111.

90. Biely P, Puls J, Schneider H. Acetyl xylan esterases in fungal cellulolytic systems. FEBS Lett. 1985;186(1):80-4.

91. Takeda K, Matsumura H, Ishida T, Samejima M, Ohno H, Yoshida M, et al. Characterization of a novel PQQ-dependent quinohemoprotein pyranose dehydrogenase from Coprinopsis cinerea classified into auxiliary activities family 12 in carbohydrate-active enzymes. PLoS One. 2015;10(2):e0115722. https://doi.org/10.1371/journal.pone.0115722.

92. Bamford NC, Le Mauff F, Subramanian AS, Yip P, Millán C, Zhang Y, et al. Ega3 from the fungal pathogen Aspergillus fumigatus is an endo-a-1, 4galactosaminidase that disrupts microbial biofilms. J Biol Chem. 2019; 294(37):13833-49.

93. Miyanaga A, Koseki T, Miwa Y, Mese Y, Nakamura S, Kuno A, et al. The family 42 carbohydrate-binding module of family 54 a-L-arabinofuranosidase specifically binds the arabinofuranose side chain of hemicellulose. Biochem J. 2006;399(3):503-11. https://doi.org/10.1042/BJ20060567.

94. Couturier M, Tangthirasunun N, Ning X, Brun S, Gautier V, Bennati-Granier C, et al. Plant biomass degrading ability of the coprophilic ascomycete fungus Podospora anserina. Biotechnol Adv. 2016;34(5):976-83. https://doi.org/10.1 016/.j.biotechadv.2016.05.010.

95. Goulet KM, Saville BJ. Carbon acquisition and metabolism changes during fungal biotrophic plant pathogenesis: insights from Ustilago maydis. Can J Plant Pathol. 2017;39(3):247-66. https://doi.org/10.1080/07060661.2017.13 54330.

96. Couger MB, Youssef NH, Struchtemeyer CG, Liggenstoffer AS, Elshahed MS. Transcriptomic analysis of lignocellulosic biomass degradation by the anaerobic fungal isolate Orpinomyces sp. strain C1A. Biotechnol Biofuels. 2015;8(1):208.

97. Olivieri F, Zanetti ME, Oliva CR, Covarrubias AA, Casalongué CA. Characterization of an extracellular serine protease of Fusarium eumartii and its action on pathogenesis related proteins. Eur J Plant Pathol. 2002;108(1):63-72.

98. Plummer KM, Clark SJ, Ellis LM, Loganathan A, Al-Samarrai TH, Rikkerink EHA, et al. Analysis of a secreted aspartic peptidase disruption mutant of Glomerella cingulata. Eur J Plant Pathol. 2004;1 10(3):265-74. https://doi.org/1 0.1023/B:EJPP.0000019796.78598.8C

99. Thon MR, Nuckles EM, Takach JE, Vaillancourt LJ. CPR1: a gene encoding a putative signal peptidase that functions in pathogenicity of Colletotrichum graminicola to maize. Mol Plant-Microbe Interact. 2002;15(2):120-8. https:// doi.org/10.1094/MPMI.2002.15.2.120.

100. Baroncelli R, Amby DB, Zapparata A, Sarrocco S, Vannacci G, Le Floch G, et al. Gene family expansions and contractions are associated with host range in plant pathogens of the genus Colletotrichum. BMC Genomics. 2016; 17(1):555. https://doi.org/10.1186/s12864-016-2917-6.

101. Jashni MK, Mehrabi R, Collemare J, Mesarich CH, De Wit PJGM. The battle in the apoplast: further insights into the roles of proteases and their inhibitors in plant-pathogen interactions. Front Plant Sci. 2015;6:584.

102. van Esse HP, van't Klooster JW, Bolton MD, Yadeta KA, Van Baarlen P, Boeren $\mathrm{S}$, et al. The Cladosporium fulvum virulence protein Avr2 inhibits host proteases required for basal defense. Plant Cell. 2008;20(7):1948-63.

103. Rooney HCE, van't Klooster JW, van der Hoorn RAL, Joosten MHAJ, Jones JDG, de Wit PJGM. Cladosporium Avr2 inhibits tomato Rcr3 protease required for Cf-2-dependent disease resistance. Science. 2005;308(5729): 1783-6. https://doi.org/10.1126/science.1111404.

104. Mueller AN, Ziemann S, Treitschke S, Aßmann D, Doehlemann G. Compatibility in the Ustilago maydis-maize interaction requires inhibition of 
host cysteine proteases by the fungal effector Pit2. PLoS Pathog. 2013;9(2): e1003177. https://doi.org/10.1371/journal.ppat.1003177.

105. Dunaevsky YE, Popova W, Semenova TA, Beliakova GA, Belozersky MA. Fungal inhibitors of proteolytic enzymes: classification, properties, possible biological roles, and perspectives for practical use. Biochimie. 2014;101:1020. https://doi.org/10.1016/j.biochi.2013.12.007.

106. Kolattukudy PE. Enzymatic penetration of the plant cuticle by fungal pathogens. Annu Rev Phytopathol. 1985;23(1):223-50.

107. Feng J, Wang F, Liu G, Greenshields D, Shen W, Kaminskyj S, et al. Analysis of a Blumeria graminis-secreted lipase reveals the importance of host epicuticular wax components for fungal adhesion and development. Mol Plant-Microbe Interact. 2009;22(12):1601-10. https://doi.org/10.1094/ MPMI-22-12-1601.

108. Gácser A, Stehr F, Kröger C, Kredics L, Schäfer W, Nosanchuk JD. Lipase 8 affects the pathogenesis of Candida albicans. Infect Immun. 2007;75(10): 4710-8.

109. Reveglia P, Savocchia S, Billones-Baaijens R, Masi M, Cimmino A, Evidente A. Phytotoxic metabolites by nine species of Botryosphaeriaceae involved in grapevine dieback in Australia and identification of those produced by Diplodia mutila, Diplodia seriata, Neofusicoccum australe and Neofusicoccum luteum. Nat Prod Res. 2019;33(15):2223-9. https://doi.org/10.1080/1478641 9.2018.1497631.

110. Reveglia P, Savocchia S, Billones-Baaijens R, Masi M, Evidente A. Spencertoxin and spencer acid, new phytotoxic derivatives of diacrylic acid and dipyridinbutan-1, 4-diol produced by Spencermartinsia viticola, a causal agent of grapevine Botryosphaeria dieback in Australia. Arab J Chem. 2020; 13(1):1803-8. https://doi.org/10.1016/j.arabjc.2018.01.014.

111. Masi M, Reveglia P, Baaijens-Billones R, Górecki M, Pescitelli G, Savocchia S, et al. Phytotoxic metabolites from three Neofusicoccum species causal agents of Botryosphaeria dieback in Australia, luteopyroxin, neoanthraquinone, and luteoxepinone, a disubstituted furo-a-pyrone, a hexasubstituted anthraquinone, and a trisubstituted oxepi-2-one from Neofusicoccum luteum. J Nat Prod. 2020;83(2):453-60. https://doi.org/10.1 021/acs.jnatprod.9b01057.

112. Evidente A, Punzo B, Andolfi A, Cimmino A, Melck D, Luque J. Lipophilic phytotoxins produced by Neofusicoccum parvum, a grapevine canker agent. Phytopathol Mediterr. 2010;49(1):74-9.

113. Burruano S, Giambra S, Mondello V, Dellagreca M, Basso S, Tuzi A, et al. Naphthalenone polyketides produced by Neofusicoccum parvum, a fungus associated with grapevine Botryosphaeria dieback. Phytopathol Mediterr. 2016:197-206.

114. Andolfi A, Basso S, Giambra S, Conigliaro G, Lo Piccolo S, Alves A, et al. Lasiolactols $a$ and $B$ produced by the grapevine fungal pathogen Lasiodiplodia mediterranea. Chem Biodivers. 2016;13(4):395-402. https://doi. org/10.1002/cbdv.201500104

115. Muria-Gonzalez MJ, Chooi YH, Breen S, Solomon PS. The past, present and future of secondary metabolite research in the Dothideomycetes. Mol Plant Pathol. 2015;16(1):92-107. https://doi.org/10.1111/mpp.12162.

116. Reveglia P, Masi M, Evidente A. Melleins-intriguing natural compounds. Biomolecules. 2020;10(5):772.

117. Tsuge T, Harimoto Y, Akimitsu K, Ohtani K, Kodama M, Akagi Y, et al. Hostselective toxins produced by the plant pathogenic fungus Alternaria alternata. FEMS Microbiol Rev. 2013;37(1):44-66.

118. Ito K, Tanaka T, Hatta R, Yamamoto M, Akimitsu K, Tsuge T. Dissection of the host range of the fungal plant pathogen Alternaria alternata by modification of secondary metabolism. Mol Microbiol. 2004;52(2):399-411.

119. Stergiopoulos I, Collemare J, Mehrabi R, De Wit PJGM. Phytotoxic secondary metabolites and peptides produced by plant pathogenic Dothideomycete fungi. FEMS Microbiol Rev. 2013;37(1):67-93.

120. Zaccaron AZ, Bluhm BH. The genome sequence of Bipolaris cookei reveals mechanisms of pathogenesis underlying target leaf spot of sorghum. Sci Rep. 2017;7(1):17217.

121. Wingfield BD, Bills GF, Dong Y, Huang W, Nel WJ, Swalarsk-Parry BS, et al. Draft genome sequence of Annulohypoxylon stygium, Aspergillus mulundensis, Berkeleyomyces basicola (syn. Thielaviopsis basicola), Ceratocystis smalleyi, two Cercospora beticola strains, Coleophoma cylindrospora, Fusarium fracticaudum, Phialophora cf. hyalina, and Morchella septimelata. IMA Fungus. 2018;9(1):199.

122. Wolpert TJ, Dunkle LD, Ciuffetti LM. Host-selective toxins and avirulence determinants: what's in a name? Annu Rev Phytopathol. 2002;40(1):251-85.

123. Grandaubert J, Lowe RG, Soyer JL, Schoch CL, Van de Wouw AP, Fudal I, et al. Transposable element-assisted evolution and adaptation to host plant within the Leptosphaeria maculans-Leptosphaeria biglobosa species complex of fungal pathogens. BMC Genomics. 2014;15(1):891. https://doi.org/10.11 86/1471-2164-15-891.

124. Testa AC, Oliver RP, Hane JK. OcculterCut: a comprehensive survey of ATrich regions in fungal genomes. Genome biology and evolution. 2016;8(6): 2044-64. https://doi.org/10.1093/gbe/evw121.

125. Andrews S. FastQC: a quality control tool for high throughput sequence data; 2010.

126. Bolger AM, Lohse M, Usadel B. Trimmomatic: a flexible trimmer for Illumina sequence data. Bioinformatics. 2014:30(15):2114-20.

127. Zerbino DR, Birney E. Velvet: algorithms for de novo short read assembly using de Bruijn graphs. Genome Res. 2008;18(5):821-9.

128. Gladman S, Seemann T. VelvetOptimiser. Victorian Bioinformatics Consortium, Clayton, Australia. 2012.https://github.com/tseemann/ VelvetOptimiser.

129. Bushnell B, Rood J, Singer E. BBMerge-accurate paired shotgun read merging via overlap. PLoS One. 2017;12(10):e0185056. https://doi.org/10.13 71/journal.pone.0185056.

130. Smit A, Hubley R. RepeatModeler-1.0.10; 2017.

131. Hoff KJ, Lange S, Lomsadze A, Borodovsky M, Stanke M. BRAKER1: unsupervised RNA-Seq-based genome annotation with GeneMark-ET and AUGUSTUS. Bioinformatics. 2015;32(5):767-9. https://doi.org/10.1093/ bioinformatics/btv661.

132. Lomsadze A, Burns PD, Borodovsky M. Integration of mapped RNA-Seq reads into automatic training of eukaryotic gene finding algorithm. Nucleic Acids Res. 2014;42(15):e119. https://doi.org/10.1093/nar/gku557.

133. Stanke M, Schöffmann O, Morgenstern B, Waack S. Gene prediction in eukaryotes with a generalized hidden Markov model that uses hints from external sources. BMC Bioinformatics. 2006;7(1):62.

134. Holt C, Yandell M. MAKER2: an annotation pipeline and genome-database management tool for second-generation genome projects. BMC Bioinformatics. 2011;12(1):491. https://doi.org/10.1186/1471-2105-12-491.

135. Waterhouse RM, Seppey M, Simão FA, Manni M, loannidis P, Klioutchnikov $\mathrm{G}$, et al. BUSCO applications from quality assessments to gene prediction and phylogenomics. Mol Biol Evol. 2017.

136. Katoh K, Standley DM. MAFFT multiple sequence alignment software version 7: improvements in performance and usability. Mol Biol Evol. 2013; 30(4):772-80. https://doi.org/10.1093/molbev/mst010.

137. Stamatakis A. RAxML version 8: a tool for phylogenetic analysis and postanalysis of large phylogenies. Bioinformatics. 2014;30(9):1312-3.

138. Lombard V, Golaconda Ramulu H, Drula E, Coutinho PM, Henrissat B. The carbohydrate-active enzymes database (CAZy) in 2013. Nucleic Acids Res. 2013;42(D1):D490-5.

139. Zhang H, Yohe T, Huang L, Entwistle S, Wu P, Yang Z, et al. dbCAN2: a meta server for automated carbohydrate-active enzyme annotation. Nucleic Acids Res. 2018;46(W1):W95-W101. https://doi.org/10.1093/nar/gky418.

140. Camacho C, Coulouris G, Avagyan V, Ma N, Papadopoulos J, Bealer K, et al. BLAST+: architecture and applications. BMC Bioinformatics. 2009;10(1):421. https://doi.org/10.1186/1471-2105-10-421.

141. Rawlings ND, Barrett AJ, Thomas PD, Huang X, Bateman A, Finn RD. The MEROPS database of proteolytic enzymes, their substrates and inhibitors in 2017 and a comparison with peptidases in the PANTHER database. Nucleic Acids Res. 2017:46(D1):D624-32.

142. Fischer M, Pleiss J. The lipase engineering database: a navigation and analysis tool for protein families. Nucleic Acids Res. 2003;31(1):319-21. https://doi.org/10.1093/nar/gkg015.

143. Eddy SR. Accelerated profile HMM searches. PLoS Comput Biol. 2011;7(10): e1002195. https://doi.org/10.1371/journal.pcbi.1002195.

144. Blin K, Shaw S, Steinke K, Villebro R, Ziemert N, Lee SY, et al. antiSMASH 5.0: updates to the secondary metabolite genome mining pipeline. Nucleic Acids Res. 2019;47(W1):W81-7.

145. Käll L, Krogh A, Sonnhammer ELL. Advantages of combined transmembrane topology and signal peptide prediction—-the Phobius web server. Nucleic Acids Res. 2007:35(suppl_2):W429-32.

146. Petersen TN, Brunak S, von Heijne G, Nielsen H. SignalP 4.0: discriminating signal peptides from transmembrane regions. Nat Methods. 2011;8(10):7856. https://doi.org/10.1038/nmeth.1701.

147. Krogh A, Larsson B, Von Heijne G, Sonnhammer ELL. Predicting transmembrane protein topology with a hidden markov model: application to complete genomes1. J Mol Biol. 2001;305(3):567-80. https://doi.org/10.1 006/jmbi.2000.4315. 
148. Pearson K. Notes on Regression and Inheritance in the Case of Two Parents Proceedings of the Royal Society of London, 58, 240-242; 1895.

149. Shapiro SS, Francia RS. An approximate analysis of variance test for normality. J Am Stat Assoc. 1972;67(337):215-6. https://doi.org/10.1080/01 621459.1972.10481232.

150. Hervé M, Hervé MM: Package 'RVAideMemoire'. https://CRANR-projectorg/ package=RVAideMemoire 2020.

151. Wilcoxon F. Individual comparisons by ranking methods. In: Breakthroughs in statistics: Springer; 1992. p. 196-202.

152. Team RC: R: a language and environment for statistical computing. 2013.

153. Conover WJ. Practical nonparametric statistics, vol. 350: Wiley; 1998.

154. Han MV, Thomas GWC, Lugo-Martinez J, Hahn MW. Estimating gene gain and loss rates in the presence of error in genome assembly and annotation using CAFE 3. Mol Biol Evol. 2013;30(8):1987-97. https://doi.org/10.1093/ molbev/mst100.

155. Sanderson MJ. r8s: inferring absolute rates of molecular evolution and divergence times in the absence of a molecular clock. Bioinformatics. 2003; 19(2):301-2. https://doi.org/10.1093/bioinformatics/19.2.301.

156. Hyde KD, Maharachchikumbura SSN, Hongsanan S, Samarakoon MC, Lücking $R$, Pem D, et al. The ranking of fungi: a tribute to David L. Hawksworth on his 70th birthday. Fungal Divers. 2017;84(1):1-23.

157. Warnes GR, Bolker B, Bonebakker L, Gentleman R, Liaw WHA, Lumley T, Maechler M, Magnusson A, Moeller S, Schwartz M: gplots: various R programming tools for plotting data. R package version 3.0. 1. The Comprehensive R Archive Network 2016.

158. Lê S, Josse J, Husson F. FactoMineR: an R package for multivariate analysis. J Stat Softw. 2008;25(1):1-18.

159. Vaissie $\mathrm{P}$, Monge $\mathrm{A}$, Husson F. Factoshiny: perform factorial analysis from FactoMineR with a shiny application, R package version, vol. 1; 2015.

160. Saunders DGO, Win J, Kamoun S, Raffaele S. Two-dimensional data binning for the analysis of genome architecture in filamentous plant pathogens and other eukaryotes. In: Plant-Pathogen Interactions: Springer; 2014. p. 29-51.

161. Smit AFA, Hubley R, Green P. RepeatMasker Open-4.0.5; 2017.

162. Van Wyk S, Harrison CH, Wingfield BD, De Vos L, van Der Merwe NA, Steenkamp ET. The RIPper, a web-based tool for genome-wide quantification of repeat-induced point (RIP) mutations. PeerJ. 2019;7:e7447.

\section{Publisher's Note}

Springer Nature remains neutral with regard to jurisdictional claims in published maps and institutional affiliations.

\section{Ready to submit your research? Choose BMC and benefit from:}

- fast, convenient online submission

- thorough peer review by experienced researchers in your field

- rapid publication on acceptance

- support for research data, including large and complex data types

- gold Open Access which fosters wider collaboration and increased citations

- maximum visibility for your research: over $100 \mathrm{M}$ website views per year

At $\mathrm{BMC}$, research is always in progress.

Learn more biomedcentral.com/submissions 